\title{
INFLUENCE OF REDOX POTENTIAL ON SELENIUM DISTRIBUTION IN GROUND WATER, MENDOTA, WESTERN SAN JOAQUIN VALLEY, CALIFORNIA
}

By Neil M. Dubrovsky, John M. Neil, Roger Fujii, Ronald S. Oremland, and J.T. Hollibaugh

U.S. GEOLOGICAL SURVEY

Open-File Report 90-138

REGIONAL AQUIFER-SYSTEM ANALYSIS 


\section{U.S. DEPARTMENT OF THE INTERIOR \\ MANUEL LUJAN, JR., Secretary}

\section{U.S. GEOLOGICAL SURVEY \\ Dallas L. Peck, Director}

Any use of trade, product, or firm names in this publication is for descriptive purposes only and does not imply endorsement by the U.S. Government.

For sale by the Books and Open-File Reports Section, U.S. Geological Survey Federal Center, Box 25425 Denver, CO 80225

For additional information write to:

District Chief

U.S. Geological Survey

Federal Building, Room W-2234

2800 Cottage Way

Sacramento, CA 95825 
This report was prepared by the U.S. Geological Survey as part of the Regional Aquifer-System Analysis (RASA) Program. The RASA Program of the U.S. Geological Survey was started in 1978 following a congressional mandate to develop quantitative appraisals of the major ground-water systems of the United States. The RASA Program represents a systematic effort to study a number of the Nation's most important aquifer systems, which in aggregate underlie much of the country and which represent an important component of the Nation's total water supply. In general, the boundaries of these studies are identified by the hydrologic extent of each system, and accordingly transcend the political subdivisions to which investigations were often arbitrarily limited in the past. The broad objectives for each study are to assemble geologic, hydrologic, and geochemical information, to analyze and develop an understanding of the system, and to develop predictive capabilities that will contribute to the effective management of the system. The Central Valley RASA study, which focused on the hydrology and geochemistry of ground water in the Central Valley of California, began in 1979. Phase II of the Central Valley RASA began in 1984 and is in progress. The focus during this second phase is on more detailed study of the hydrology and geochemistry of ground water in the San Joaquin Valley, which is the southern half of the Central Valley. 


\title{
CONTENTS
}

\author{
Abstract 1 \\ Introduction 1 \\ Hydrogeologic setting 2 \\ Stratigraphy 2 \\ Hydrology 4 \\ Methods 6 \\ Field 6 \\ Well sampling 6 \\ Laboratory 7 \\ Core sampling 6 \\ General water chemistry 7 \\ Age and origin of ground water 8 \\ Distribution of selenium 14 \\ Influence of redox potential on selenium distribution 16 \\ Summary and conclusions 21 \\ References cited 22
}

\section{FIGURES}

1. Maps showing location of study site 3

2. Lithologic log of the upper 60 feet of sediment from continuous core from observation well P1-55 4

3-4. Graphs showing:

3. Water-level changes from 1957 to 1985 for two production wells near the study site 5

4. Seasonal fluctuations in potentiometric heads in observation wells, April 1987 through July $1988 \quad 6$

5. Profile showing specific conductance of porewater samples from three cores and ground-water samples from observation wells 8

6. Trilinear diagram showing major-ion chemistry of ground-water samples from observation wells 9

7. Profile showing delta oxygen-18 ratios in ground-water and porewater samples and tritium concentrations in ground-water samples 11

8. Graph showing delta deuterium and delta oxygen-18 for ground-water and porewater samples 14

9-12. Profiles showing:

9. Selenium concentrations in porewater samples 15

10. Platinum electrode redox potential and concentrations of iron and manganese in ground-water samples 17

11. Concentration of manganese in porewater samples from 1987 (P1-55 and P1-49) and 1988 (P1-63) 18

12. Selenium concentrations in porewater samples from the P1-63 core and results of assays of potential selenate reduction for sediments from the P1-37 core, expressed as percentage of total ${ }^{75} \mathrm{SeO}_{4}$ lost from solution 19

13. Diagram showing selenium concentrations in two sets of soil samples in the San Joaquin Valley: 297 soil samples from 0 to 12 inches collected valleywide and 721 soil samples from 66 to 72 inches from the Panoche and Cantua alluvial fans 20

14. Profile showing selenium concentrations of porewater and sediment samples extracted from cores during drilling of obscrvation wells P1-49 and P1-55 21 


\section{TABLES}

1. Analyses of ground-water samples from observation wclls for major constituents and selenium $\mathbf{1 0}$

2. Analyses of ground-water samples from observation wells for tritium, delta deuterium, and delta oxygen-18 11

3. Geochemical data for porewater samples from cores Pl-55 and P1-49, April 1987; and P1-63, August 9-10, 198812

4. Indicators of redox potential for ground-water samples from wclls 16

5. Selenate reduction potential in sediment samples from undisturbed core Pl-37 collected August 1988; expressed as percentage of total ${ }^{75} \mathrm{ScO}_{4}$ removed from solution 19

6. Selenium concentrations in sediment samples from cores Pl-55 and Pl-49, April 198720

\section{Conversion Factors}

For readers who prefer to use the International System of Units (SI) rather than inch-pound units, the conversion factors for terms used in this report are listed below.

\begin{tabular}{rcl}
\hline Multiply & By & To obtain \\
\hline foot (ft) & 0.3048 & meter \\
inch (in.) & 25.4 & millimeter \\
mile (mi) & 1.6093 & kilometer \\
pound per square inch (lb/in $\left.{ }^{2}\right)$ & 6.895 & kilopascal \\
\hline
\end{tabular}

Abbreviations:

$\mathrm{g} / \mathrm{L} \quad$ gram per liter

$\mu \mathrm{g} / \mathrm{g} \quad$ microgram per gram

$\mu \mathrm{m} \quad$ micrometer

$\mu \mathrm{g} / \mathrm{L} \quad$ microgram per liter

$\mu \mathrm{S} / \mathrm{cm} \quad$ microsiemen per centimeter

$\mathrm{mg} / \mathrm{L} \quad$ milligram per liter

$\mathrm{mL} \quad$ milliliter

$\mathrm{mm} / \mathrm{d} \quad$ millimeter per day

$\mathrm{mM} \quad$ millimole

$\mathrm{mV} \quad$ millivolt

$\mathrm{Tu} \quad$ tritium unit equation:

Temperature is given in degrees Celsius $\left({ }^{\circ} \mathrm{C}\right)$, which can be converted to degrees Fahrenheit $\left({ }^{\circ} \mathrm{F}\right)$ by the following

$$
{ }^{\circ} \mathrm{F}=1.8\left({ }^{\circ} \mathrm{C}\right)+32
$$

Sea Level: In this report "sea level" refers to the National Geodetic Vertical Datum of 1929 (NGVD of 1929)--a geodetic datum derived from general adjustment of the first-order level nets of both the United States and Canada, formerly called "Sea Level Datum of 1929." 


\title{
INFLUENCE OF REDOX POTENTIAL ON SELENIUM
}

\section{DISTRIBUTION IN GROUND WATER, MENDOTA,}

\author{
WESTERN SAN JOAQUIN VALLEY, CALIFORNIA
}

\author{
By Neil M. Dubrovsky, John M. Neil, Roger Fujii, Ronald S. Oremland,
} and J.T. Hollibaugh

\begin{abstract}
The influence of redox potential on selenium transport in shallow ground water was investigated at a site in Mendota, in the western San Joaquin Valley, California. Stratigraphy at the site consists of about 50 feet of complexly interbedded sediments from Sierra Nevada and Coast Range sources, overlying a thick aquifer of Sierra Nevada origin. Under natural conditions, the site was a groundwater discharge area; however, the water table has declined to its present position of 17 to 27 feet below land surface as a result of extensive pumping from the underlying aquifer.
\end{abstract}

Detailed profiles of ground-water chemistry obtained from wells and from porewater extracted from undisturbed cores show saline water at shallow depths. Specific conductance peaks at greater than 20,000 microsiemens per centimeter at a depth of 36 to 48 feet, and decreases to 3,270 microsiemens per centimeter at a depth of 60 feet. A sharply bounded zone containing water with selenium concentrations greater than 100 micrograms per liter is present at a depth between 18 and 28 feet, with a peak of 1,520 micrograms per liter at a depth of 22.5 feet. Selenium and specific conductance were not correlated in ground water at the site in contrast to the high correlation for ground water from oxidized Coast Range sediments to the west. Redox indicators suggest that the lack of correlation is due to removal of selenium from solution by reduction to a less mobile species. This is inferred by the coincidence of the lower boundary of the high selenium zone with (1) decreasing platinum electrode redox potentials, (2) the disappearance of dissolved oxygen and nitrate, and (3) a rapid increase in iron and manganese concentrations. Laboratory analyses of undisturbed cores indicate that the mechanism of selenium removal is likely microbial reduction to insoluble elemental selenium.

The conceptual model for the site consists of the evolution of saline soil with high selenium concentrations in a regional ground-water discharge area prior to agricultural development; downward migration of saline, seleniferous ground water due to water-table drawdown; and selenium removal from the downward-migrating ground water by microbially mediated redox reactions.

\section{INTRODUCTION}

High concentrations of the trace element selenium in agricultural drain water in the western San Joaquin Valley, California, has been a source of concern since 1983. High selenium concentrations in agricultural drain water entering Kesterson Reservoir apparently were responsible for high mortality rates among waterfowl at the reservoir (Ohlendorf and others, 1986). This finding stimulated research aimed at determining the processes that control the mobility and transport of selenium in ground water in the western San Joaquin Valley. Results of the research show that selenium is correlated with ground-water salinity (Deverel and Fujii, 1988; Deverel and Millard, 1988). Selenium concentrations as high as several thousand micrograms per liter occur in shallow saline ground water that has evolved as a result of leaching of natural soil salts and concentration of dissolved solids by evapotranspiration in areas where the water table is near the land surface (Deverel and Fujii, 1988). Under natural conditions, selenium accumulated in areas with a shallow water table primarily in the ground-water discharge zone near the axis of the valley. Application of large quantities of irrigation water have caused a rapid expansion of areas affected by shallow water tables and salt accumulation problems (Belitz and Heimes, 1990; San Joaquin Valley Drainage Program, 1989). 
Research has focused on the Panoche Creek and Cantua Creek alluvial fans in western Fresno County because regional studies showed that these areas have the highest concentrations of selenium in the soil (Tidball and others, 1986) and shallow ground water (Deverel and others, 1984). Cross sections of groundwater chemistry in wells installed in the Panoche Creek alluvial fan show that ground water derived from recent irrigation recharge, identifiable by its tritium concentration, has infiltrated the aquifers to a depth of 50 to $150 \mathrm{ft}$ below the water table (Dubrovsky and Deverel, 1989). This agricultural recharge contains high concentrations of dissolved solids, selenium, and other trace elements.

Although most irrigation water applied in the western San Joaquin Valley is imported from the Sacramento-San Joaquin Delta by canals, large quantities of ground water are still pumped for various uses. Most of this ground water is withdrawn from Sierra Nevada sediments that underlie flood-basin deposits or alluvial-fan sediments derived from the Coast Range. Permeability generally is higher in the Sierra Nevada sediments than Coast Range sediments (Miller and others, 1971; Bull and Miller, 1975). Most water from the Sierra Nevada sediments is of better quality than water from the Coast Range sediments (Miller and others, 1971, p. 39). Ground water in Sierra Nevada sediments generally is more reducing than ground water in Coast Range sediments (Davis and Poland, 1957; Hotchkiss and Balding, 1971; Lettis, 1982; and Dubrovsky, 1989).

An important concern for water management in this area is the potential contamination of the extensively used aquifer in the Sierra Nevada sediments by overlying high-selenium, shallow ground water in Coast Range sediments. The present-day direction of ground-water flow in the western part of the valley trough, where the potential for such contamination is greatest, is downward and eastward. Moreover, downward and eastward flow could be increased by management strategies that use pumping of deep wells in Sierra Nevada sediments to control the water table. There is a possibility, however, that selenium in shallow ground water that moves across the boundary of the Coast Rarige and Sierra Nevada sediments may be removed from solution due to the low solubility of selenium in the chemically reducing conditions that prevail in the Sierra Nevada sediments.

This research was conducted as part of the Regional Aquifer-System Analysis Program of the U.S. Geological Survey. The purposes of this study were to determine the vertical distribution of selenium in ground water across the lithologic interface of Coast Range and Sierra Nevada sediments and to evaluate the influence of ground-water redox potential on selenium concentrations. A site at the eastern edge of the Panoche Creek alluvial fan in Mendota was selected for study because the interface of Coast Range and Sierra Nevada sediments is at a shallow depth, facilitating detailed sampling. The site also was selected because a geochemical control on selenium concentrations was indicated by preliminary data showing that selenium concentrations in ground water decreased from almost $500 \mu \mathrm{g} / \mathrm{L}$ in ground water from Coast Range sediments at a depth of $24 \mathrm{ft}$ to less than $1 \mu \mathrm{g} / \mathrm{L}$ in ground water from Sierra Nevada sand at a depth of $60 \mathrm{ft}$. The approach was to determine the vertical distribution of selenium and other pertinent constituents in the ground water by sampling observation wells and extracting porewater from undisturbed cores. The selenium concentration of the sediments also was determined, and the potential for selenium reduction by microbial processes was evaluated.

\section{HYDROGEOLOGIC SETTING}

The study site was in Mendota, California, about $1 \mathrm{mi}$ southwest of the San Joaquin River near the center of the San Joaquin Valley (fig. 1). The climate of the area is semiarid with a mean annual precipitation of about $12 \mathrm{in}$. The site has never been farmed and, until recently, was on undeveloped land at the Mendota municipal airfield.

\section{STRATIGRAPHY}

The general stratigraphy of the study site consists of about $55 \mathrm{ft}$ of predominantly fine-grained deposits underlain by about $400 \mathrm{ft}$ of medium- to coarsegrained, well-sorted sand. The geologic map of the San Joaquin Valley identifies the surficial sediments as recent flood-basin deposits of the .San Joaquin River (California Division of Mines and Geology, 1959). A more recent evaluation concluded that the surficial geology of the site consists of fine-grained Coast Range sediments deposited at the toe of the Panoche Creek alluvial fan (Lettis, 1982). Mediumto coarse-grained sand at greater depths is a mixture of river channel and alluvial-fan sediments derived from the Sierra Nevada and deposited at a time when the axis of the San Joaquin Valley was west of its present position. 

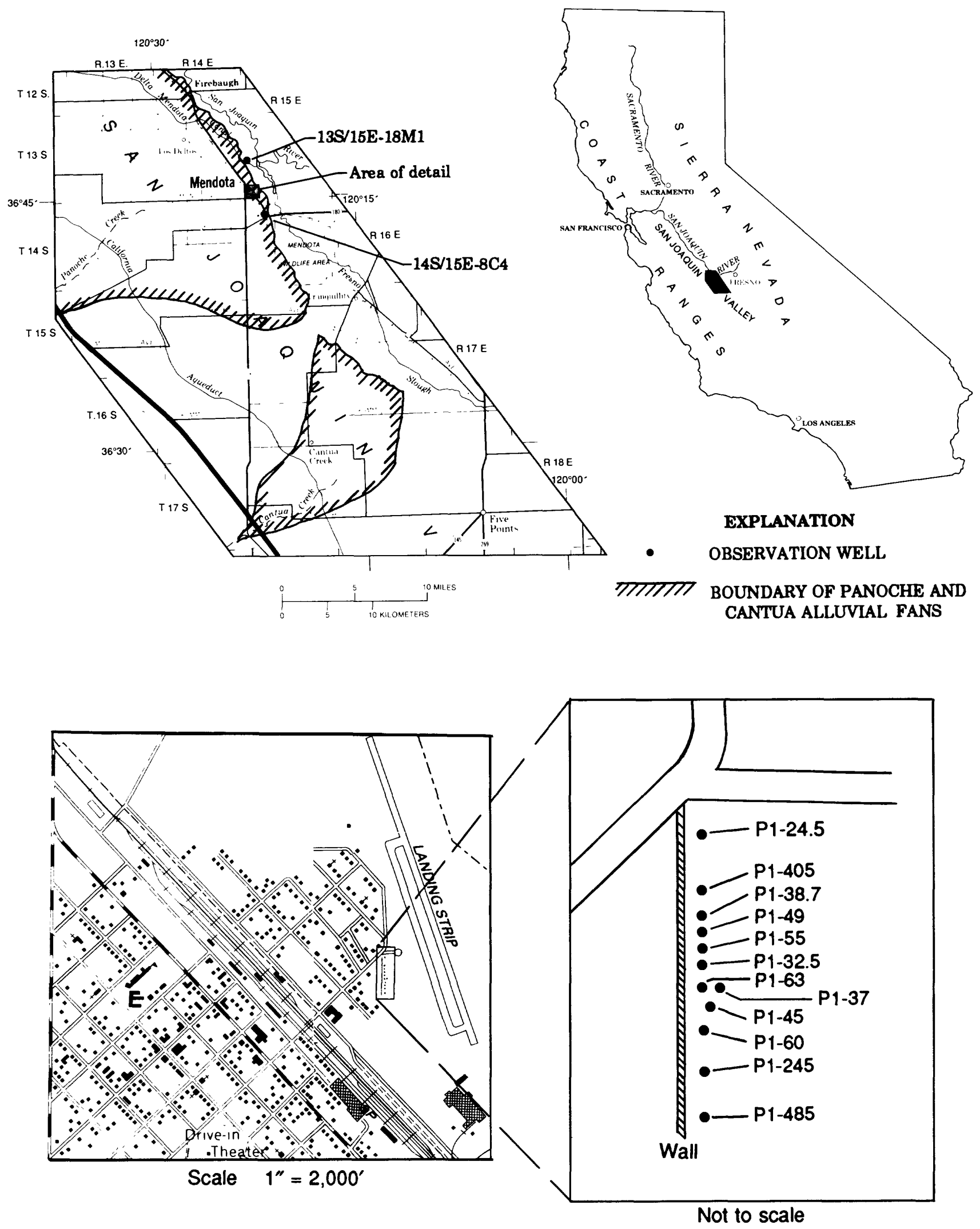

Figure 1. Location of study site. 
The upper $60 \mathrm{ft}$ of sediment at the site was continuously cored in the Pl- 55 borehole and logged in detail to better define the source area of the sediment and the depositional environment. The lithology in this interval showed a large range in grain size, color, structure, and gypsum content (fig. 2). The upper $11 \mathrm{ft}$ was a buff sandy clay loam with abundant root structure and secondary gypsum and calcite in the upper $7 \mathrm{ft}$. This was followed by a transition zone where fine-grained layers of clay and silt alternate with thin layers of sand, some of which show strong iron hydroxide staining. Mottling occurred at about $14 \mathrm{ft}$ and intensified over the next $10 \mathrm{ft}$ with reduced gray sediments gradually predominating. From about a depth of 26 to $60 \mathrm{ft}$, the sediments were blue gray. Medium- to coarse-grained sand predominated from about a depth of 26 to $42 \mathrm{ft}$, followed by silty sand, and medium- to coarse-grained sand at a depth greater than about $54 \mathrm{ft}$.

The source of the sediment at the site is important because the concentration of selenium in Coast Range sediments is higher than in Sierra Nevada sediments (Tidball and others, 1986), and reactions between the sediments and ground water may release selenium into solution. The source area usually is determined on the basis of mineralogy and lithic fragments (Meade, 1967, p. 5). On the basis of these criteria, medium- and coarse-grained sand at depths greater than about $26 \mathrm{ft}$ were derived almost exclusively from the Sierra Nevada. Identification on this basis is difficult when the sediment is fine grained. Most of the fine-grained sediment in the upper $26 \mathrm{ft}$ probably is derived from the Coast Range because of its high salinity, geomorphic location, and interbedding with coarser grained Coast Range sediments.

\section{HYDROLOGY}

The study site was in the western part of the valley trough where artesian conditions occurred in the semiconfined zone under natural conditions (Mendenhall and others, 1916), and marshland was present prior to development (Hamilton, 1916). Soil at the site was highly saline with greater than 1 percent total soluble solids by weight (Harradine, 1950). The accumulation of soil salts requires a shallow water table, which along with the observations noted above, indicates that the site was an area of ground-water discharge for most of the year. This observation is significant because high selenium concentrations in shallow ground water generally are associated with saline soils in the western San Joaquin Valley (Deverel and Gallanthine, 1989).

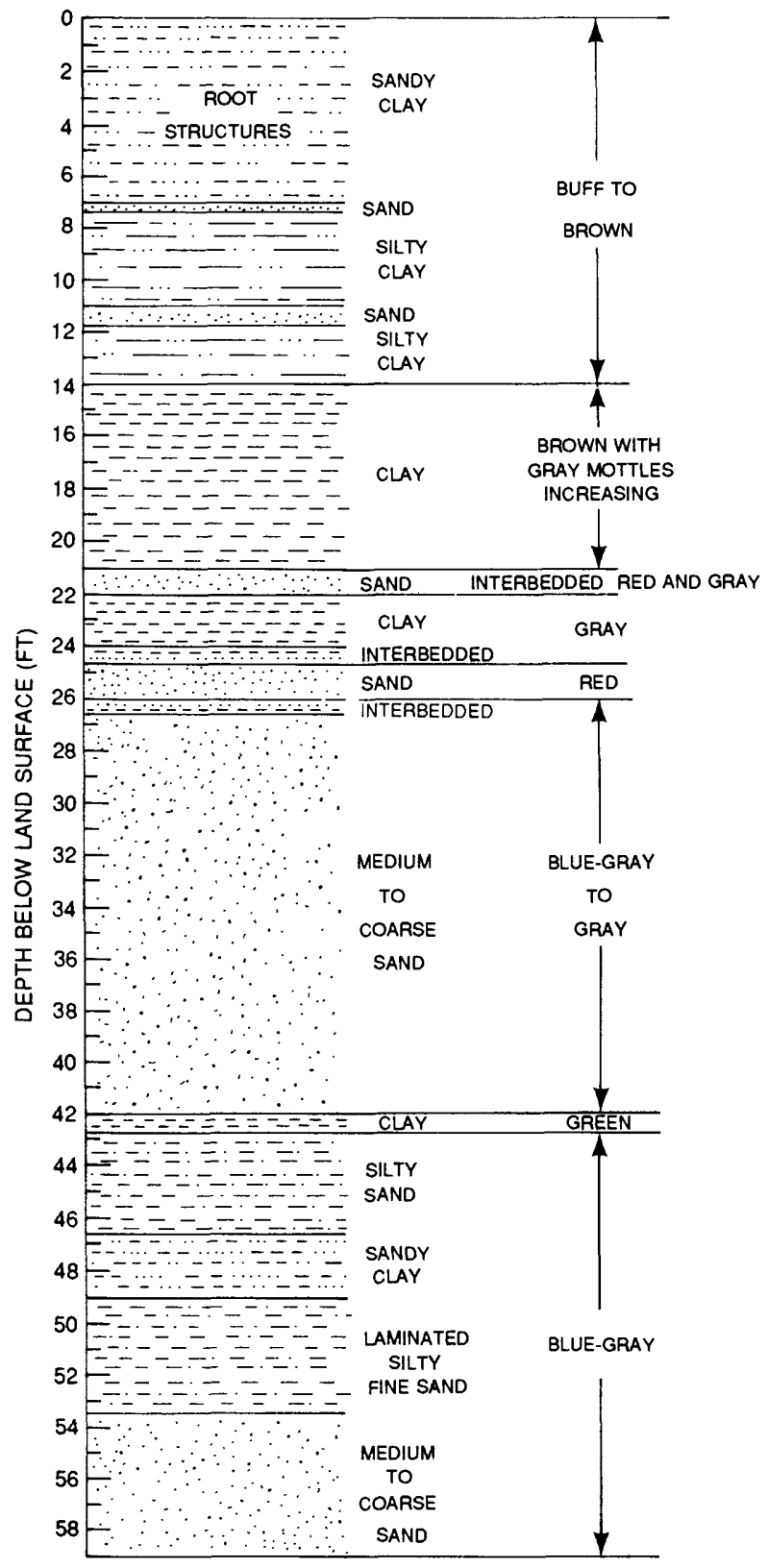

Figure 2. Lithologic log of the upper 60 feet of sediment from continuous core from observation well $\mathrm{PI}-55$.

Prior to construction of reservoirs on the major Sierra Nevada rivers, ground-water recharge to the site was due to seasonal flooding by Sierra Nevada runoff in the San Joaquin River and Fresno Slough. Small amounts of additional recharge may have occurred as a result of sparse annual precipitation and infrequent high flows in Panoche Creek. Maps of the irrigation history of the central western San Joaquin Valley show that by 1955 most of the area 
surrounding the site at a distance of $1 \mathrm{mi}$ was irrigated by ground water; however, interviews with local officials indicated that the site has never been irrigated. At present, the town of Mendota and irrigated fields immediately west of the site are the closest source of recharge although the quantity of water that infiltrates from leaking water mains, lawn watering, or other municipal uses is not known.

The rapid development of agriculture, particularly following World War II, required large quantities of irrigation water. Most of this demand was met by ground-water withdrawals, which resulted in regional declines in the water table (Belitz and Heimes, 1990). The large quantities of ground-water withdrawal resulted in a lowering of the water table in distal areas of the alluvial fans. A comparison of watertable maps for the area in 1908 and 1952 shows that the water-table altitude decreased by about $20 \mathrm{ft}$ at the study site (Belitz and Heimes, 1990). Extensive ground-water pumping, and likely additional watertable decline, continued until 1967 after which pumping decreased due to the use of surface water imported by the California Aqueduct (Belitz and Heimes, 1990, fig. 10).

Following the decrease in pumping after 1967, water levels near the site recovered. Data for well $13 \mathrm{~S} / 15 \mathrm{E}-18 \mathrm{M} 1$ about $3 \mathrm{mi}$ northwest of the study site indicate a steady decline in water levels from 1959 to 1967 for a total decline of about $25 \mathrm{ft}$ (fig. 3). The water levels were erratic during 1967-75; however, water levels rose about $25 \mathrm{ft}$ during 1978-84 to an altitude equal to or greater than those in 1958. Water levels for well 14S/15E-8C4 about $2 \mathrm{mi}$ southeast of the study site show no change from 1963 to 1969; however, water-level altitude shows a uniform rate of increase from 1969 through 1984 for a total of about $35 \mathrm{ft}$ of recovery (fig. 3). Although no records are available for the site itself, data for these wells indicate that the water table at the site probably was drawn down 20 to $35 \mathrm{ft}$ or more by ground-water pumping compared to the predevelopment conditions and has recovered since the decrease in ground-water withdrawal in 1967. Recovery may be less than in adjacent areas due to the absence of irrigation recharge at the site, and the present water-table altitude probably is lower than under natural conditions but higher than in the recent past.

Data for the observation wells at the study site showed seasonal fluctuations in the potentiometric heads (fig. 4) from April 1987 through July 1988. In April 1987, the water level in the 24.5-foot well was $18.2 \mathrm{ft}$ below the land surface of $152 \mathrm{ft}$, and there was a steep downward gradient between the 38.7- and 55-foot wells. From April to August, the water levels declined in all wells almost uniformly, with a slight increase in the downward gradient near the bottom of the section. In September, the water table reached a maximum depth of $26.0 \mathrm{ft}$ below land surface, and there was a reversal in the gradient as the water levels in wells at 55 and $49 \mathrm{ft}$ increased by about $1 \mathrm{ft}$. The water levels rose in all wells through the autumn and winter, and upward gradients persisted throughout the profile until March. From February to March, water levels in the lower two wells declined by about $2 \mathrm{ft}$, and downward gradients were again established.

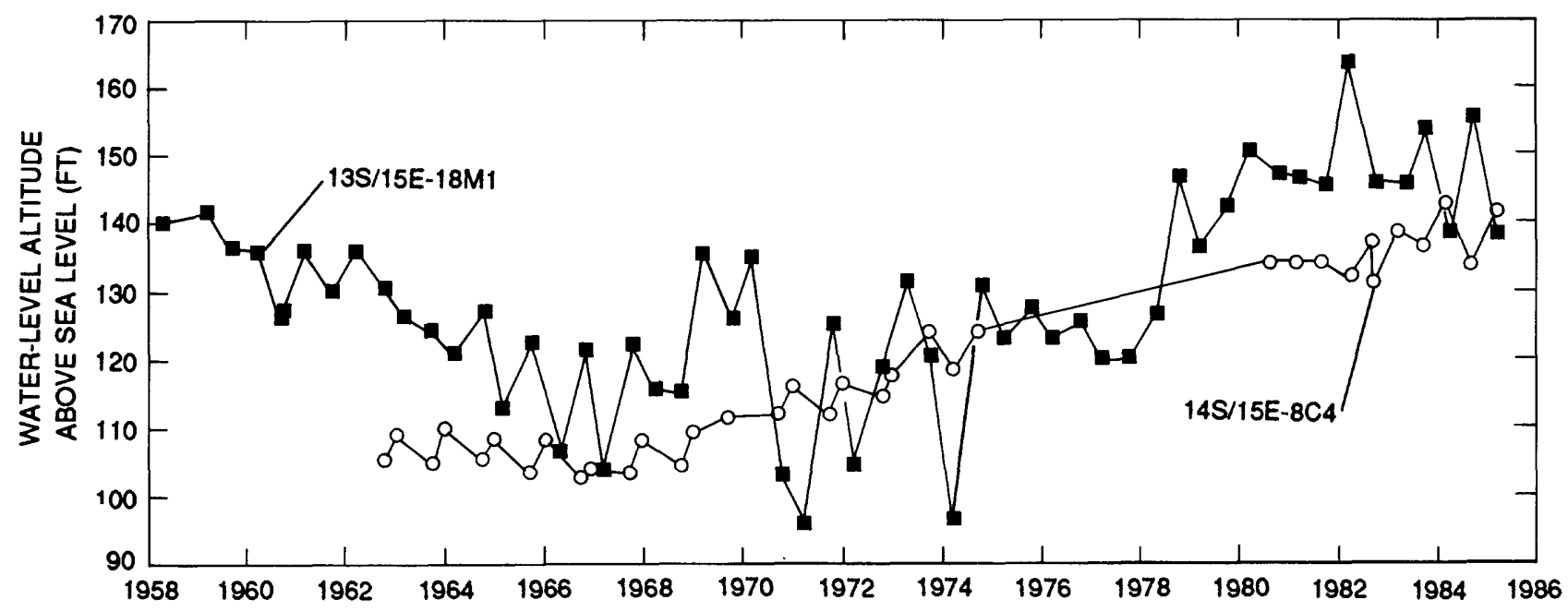

Figure 3. Water-level changes from 1957 to 1985 for two production wells near the study site. 


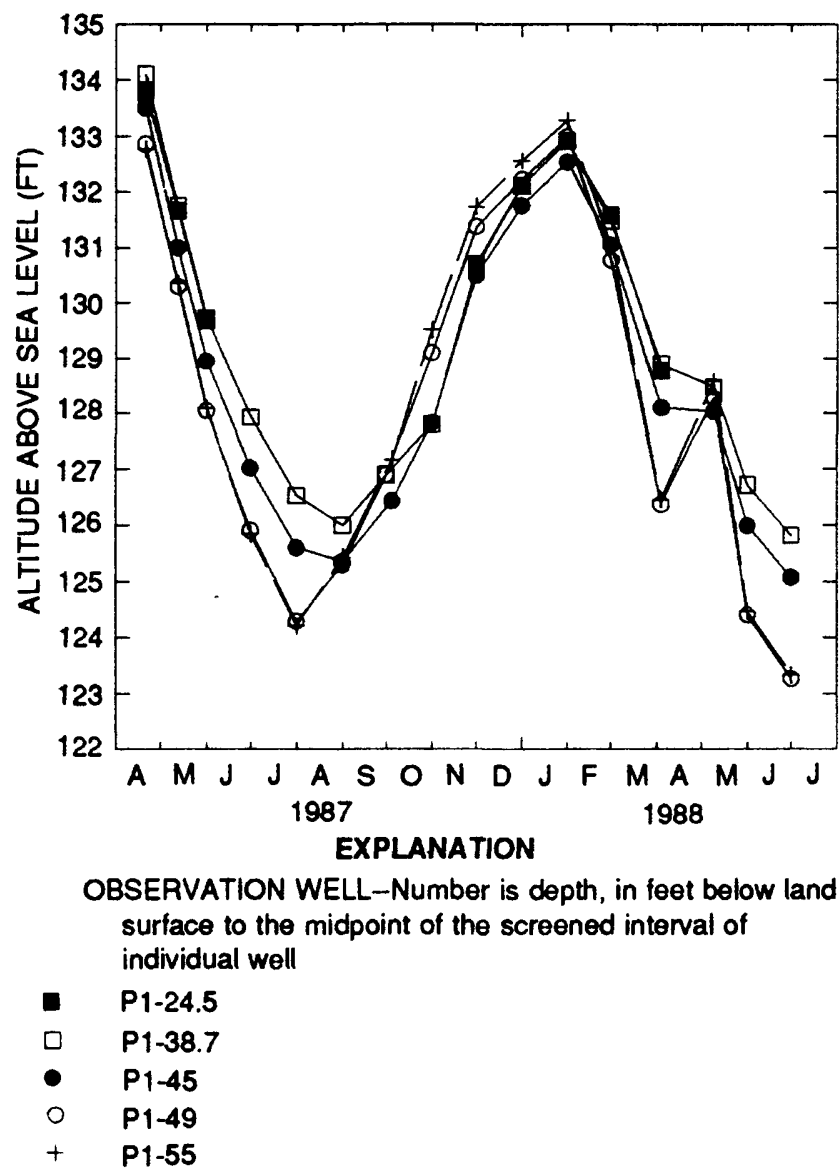

Figure 4. Seasonal fluctuations in potentiometric heads in observation wells, April 1987 through July 1988.

The declining water levels in the spring and summer correspond to a period when the Sierra Nevada sediments are extensively pumped for irrigation and agricultural processing water. The quantity of pumping is greatly decreased in the early autumn, resulting in water-level recovery. This seasonal water use results in maximum fluctuations of more than $7.5 \mathrm{ft}$ in the overlying Coast Range sediment. This is larger than the 1- to 5-foot seasonal fluctuation measured for wells higher up on the Coast Range alluvial fans in irrigated areas that are not drained (Bclitz and Heimes, 1990) and probably is larger than the seasonal fluctuation in the predevelopment flow system.

\section{METHODS}

FIELD

Data on the hydrology and chemistry of the site were collected by two methods: installation of observation wells and recovery of porewater and sediment samples from undisturbed core. Initially, three wells were drilled and completed at depths of 24 to $245 \mathrm{ft}$. Subsequently, five additional wells were drilled and completed at depths between 25 and $60 \mathrm{ft}$ in order to obtain more detail on the vertical distribution of ground-water chemistry. All wells at depths less than $60 \mathrm{ft}$ were completed using a hollow stem auger and 2 -inch PVC pipe with screen lengths of 2 to $10 \mathrm{ft}$. The screened interval of these wells was sandpacked and isolated using a bentonite grout. In the deeper wells, 6-inch PVC casings were installed with 10-foot screens using mud rotary drilling, sandpacked, and then grouted to land surface. Wells were monitored for water levels, and water-quality samples were collected.

\section{WELL SAMPLING}

Prior to sample collection, wells were purged of three casing volumes of water or until the specific conductance stabilized to within 10 percent in consecutive casing volumes. During this period, a flow-through cell was used to monitor temperature, $\mathrm{pH}$, dissolved-oxygen concentrations, and platinum electrode redox potential (in $\mathrm{mV}$ ) of the ground water without exposing it to the atmosphere. The $\mathrm{pH}$ meters and electrodes used were calibrated using $\mathrm{pH}$ 7 and 10 buffers before each measurement. The platinum electrode was checked against ZoBell's solution (Nordstrom, 1977).

\section{CORE SAMPLING}

Detailed information on the vertical variation in ground water and sediment chemistry was collected by extracting porewater from continuous, undisturbed cores. Two-foot core intervals were collected by inserting a core barrel lined with two 1-foot long 
sections of 2-inch diameter clear plastic tubing down the annulus of a hollow stem auger. Porewater was hydraulically extracted in the field using a procedure similar to the ones described by Siever (1962) and Manheim (1966). Each 1-foot section was subsampled for porewater as soon as each core was recovered. Two sets of cores, P1-55 and P1-63, were processed at the site immediately after collection, and the P1-49 core was returned to the laboratory for porewater extraction. Samples from core P1-37 were sealed and stored on ice immediately upon collection for subsequent analysis of selenate reduction by microbial activity.

Specific conductance was measured on all porewater samples as soon as they were extracted. In addition, samples were collected for the analysis of total selenium, selenium species, major elements, and the stable isotopes of oxygen and hydrogen. The samples for selenium speciation analysis were filtered through a $0.45-\mu \mathrm{m}$ filter and acidified using concentrated hydrochloric acid, then all samples were chilled.

Water samples to be analyzed for major and trace dissolved constituents were filtered immediately upon collection using $0.45-\mu \mathrm{m}$ membrane filters and stored in polyethylene bottles. All bottles and sampling equipment were rinsed three times with the water to be sampled prior to sample collection. Samples collected for cation analysis were preserved by using nitric acid. Samples for anion analysis and specific conductance were untreated although the sample for nitrogen species was chilled. An unfiltered sample for analysis of total organic carbon was collected in a glass bottle. Unfiltered samples for tritium and the stable isotopes of oxygen and hydrogen also were collected in glass bottles with polyseal tops. Incremental alkalinity titrations were done on unfiltered samples as soon as the sample was collected.

\section{LABORATORY}

Major and trace elements were analyzed by the U.S. Geological Survey's National Water Quality Laboratory in Arvada, Colorado, by standard methods described by Skougstad and others (1985). Complete analyses of major constituents were done only on well samples. Arsenic and selenium concentrations were determined by hydride generation and atomic absorption spectrometry.

The porewater samples were analyzed for total selenium and, where a sufficient volume was available, selenium species in the laboratory of the U.S. Geological Survey, Sacramento, California, according to the methods described in Fio and Fujii (1990). Manganese concentrations were analyzed on porewater samples preserved with $0.1 \mathrm{~mL}$ nitric acid by standard methods (Skougstad and others, 1985) at the U.S. Bureau of Reclamation Laboratory in Sacramento, California, in 1987 and the U.S. Geological Survey National Water Quality Laboratory in 1988. The stable isotopes of oxygen and hydrogen were analyzed at the Isotope Fractionation Laboratory of the U.S. Geological Survey in Reston, Virginia, according to the methods in Epstein and Mayeda (1953) and Kendall and Coplen (1985), respectively. Stable-isotopes results are reported relative to Vienna Standard Mean Oceanic Water (V-SMOW) in per mil notation (\%o). Tritium analysis was done by electrolytic enrichment followed by scintillation counting (International Atomic Energy Agency, 1976) by the Environmental Isotope Laboratory at the University of Waterloo, Ontario, Canada.

\section{GENERAL WATER CHEMISTRY}

Both porewater and ground-water samples show a zone of high but variable salinity at depths between 12 and $55 \mathrm{ft}$. The specific conductance of porewater from three cores collected during more than 1 year, ranged from $7,040 \mu \mathrm{S} / \mathrm{cm}$ at $56.1 \mathrm{ft}$ below land surface to $27,100 \mu \mathrm{S} / \mathrm{cm}$ at 43.0 and $44.8 \mathrm{ft}$ below land surface (fig. 5). Ground-water samples show the same profile and indicate that, in addition, specific conductance ranged from 3,000 to $4,000 \mu \mathrm{S} / \mathrm{cm}$ at depths equal to or greater than $60 \mathrm{ft}$. Specific conductance at depths less than $60 \mathrm{ft}$ is more than two orders of magnitude greater than specific conductance of surface water draining the Sierra Nevada. 


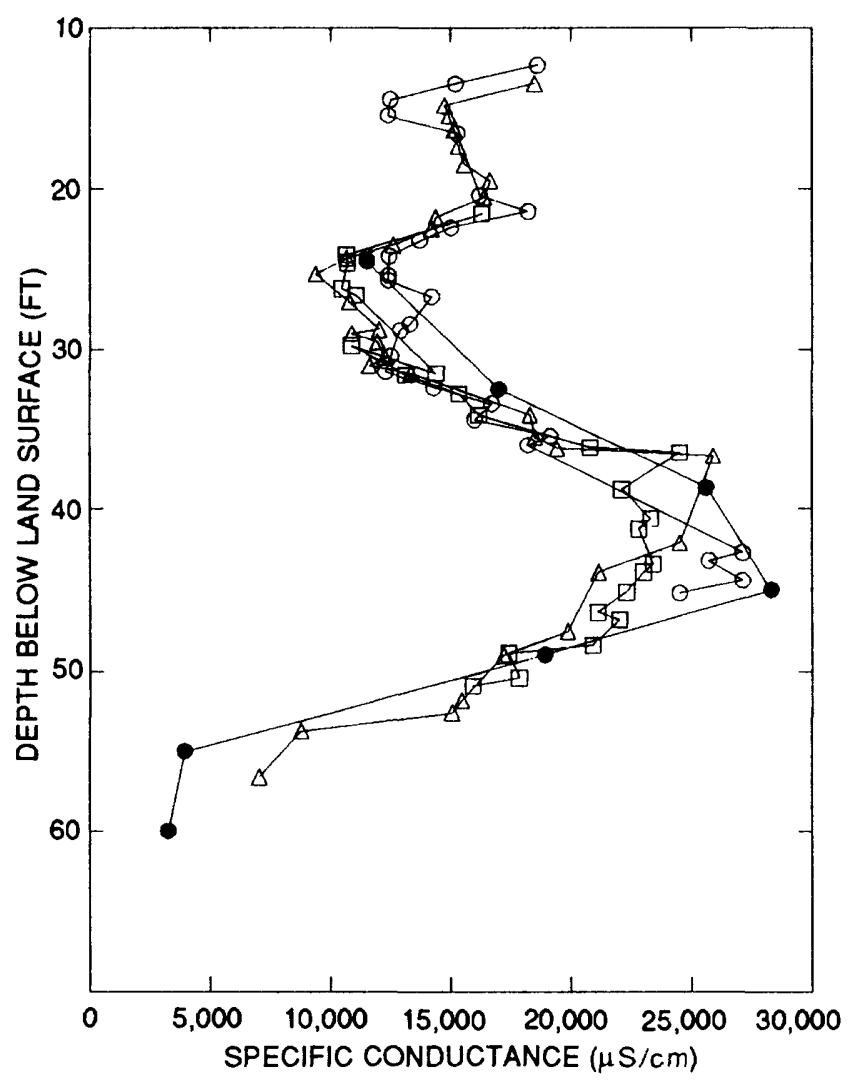

EXPLANATION

POREWATER SAMPLE EXTRACTED FROM CORES--Core samples were collected during drilling of observation wells P1-49

P1-55

P1-63

GROUND-WATER SAMPLES FROM OBSERVATION WELLS

Figure 5. Specific conductance of porewater samples from three cores and ground-water samples from observation wells.

The major-ion chemistry of ground-water samples is plotted in figure 6 (table 1). In addition to the data for the shallow wells, the analysis of a sample from a well completed at $245 \mathrm{ft}$, which is typical of deeper ground water at the site, is included for comparison. All ground water sampled was classified as sodium chloride water with sodium always greater than
66 percent of the cation equivalents and chloride always greater than 57 percent of the anion equivalents. Ground water from the wells at depths between 32 and $49 \mathrm{ft}$ have very similar cation ratios. Anion ratios in these samples showed a constant proportion of carbonate plus bicarbonate but an inverse proportionality between chloride and sulfate. Saline sodium chloride ground water also was reported by Davis and others (1959, p. 176) near the valley axis.

The chemical similarity of water from depths of 32.5 to $49 \mathrm{ft}$ indicates a common origin and history attributed to a combination of the concentration of dissolved solids by evapotranspiration and the redissolution of soil salts produced by earlier cycles of desiccation. The decrease in dissolved-solids concentrations from a depth of 45 to $60 \mathrm{ft}$ is the result of mixing shallow, saline ground water with deep ground water with lower dissolved-solids concentrations.

\section{AGE AND ORIGIN OF GROUND WATER}

The stable-isotope composition of ground water along with tritium dating were used to help evaluate the age and origin of ground water. The profile of the delta oxygen-18 $\left(\delta^{18} \mathrm{O}\right)$ in ground-water samples show similar values ranging from -9.00 to $-9.95 \%$ o at depths of 24.5 to $49 \mathrm{ft}$ (fig. 7, table 2). Delta oxygen-18 was $-10.85 \%$ for ground water in wells at depths of 55 and $60 \mathrm{ft}$. The values for the deeper wells are similar to the value of $-11.10 \%$ in the 245-foot well, as well as the $\delta^{18} \mathrm{O}$ of about $-11 \%$ o for imported canal water (Deverel and Gallanthine, 1989) used for irrigation in the western San Joaquin Valley. The similarity of the irrigation water and the deep ground water precludes identification of the source of the shallow water solely on the basis of oxygen isotopes. Porewater samples from 25.3 to $50.4 \mathrm{ft}$ had $\delta^{18} \mathrm{O}$ values similar to ground water from wells at similar depths (fig. 7, table 3). Porewater data shows a significant enrichment in $\delta^{18} \mathrm{O}$ from $-9.90 \%$ at a depth of $25.3 \mathrm{ft}$ to a maximum of -5.70 $\% o$ at a depth of $13.5 \mathrm{ft}$, slightly above the water table (fig. 7). Enrichment in $\delta^{18} \mathrm{O}$ indicates that the shallower porewater has undergone evaporation. 


\section{EXPLANATION}

OBSERVATION WELL--Number is depth, in feet below land surface to the midpoint of the screened interval of individual well

P1-24.5

O P1-32.5

$+\quad P 1-38.7$

$\times \quad P 1-45$

$\diamond \quad P 1-49$

P1-55

P1-60

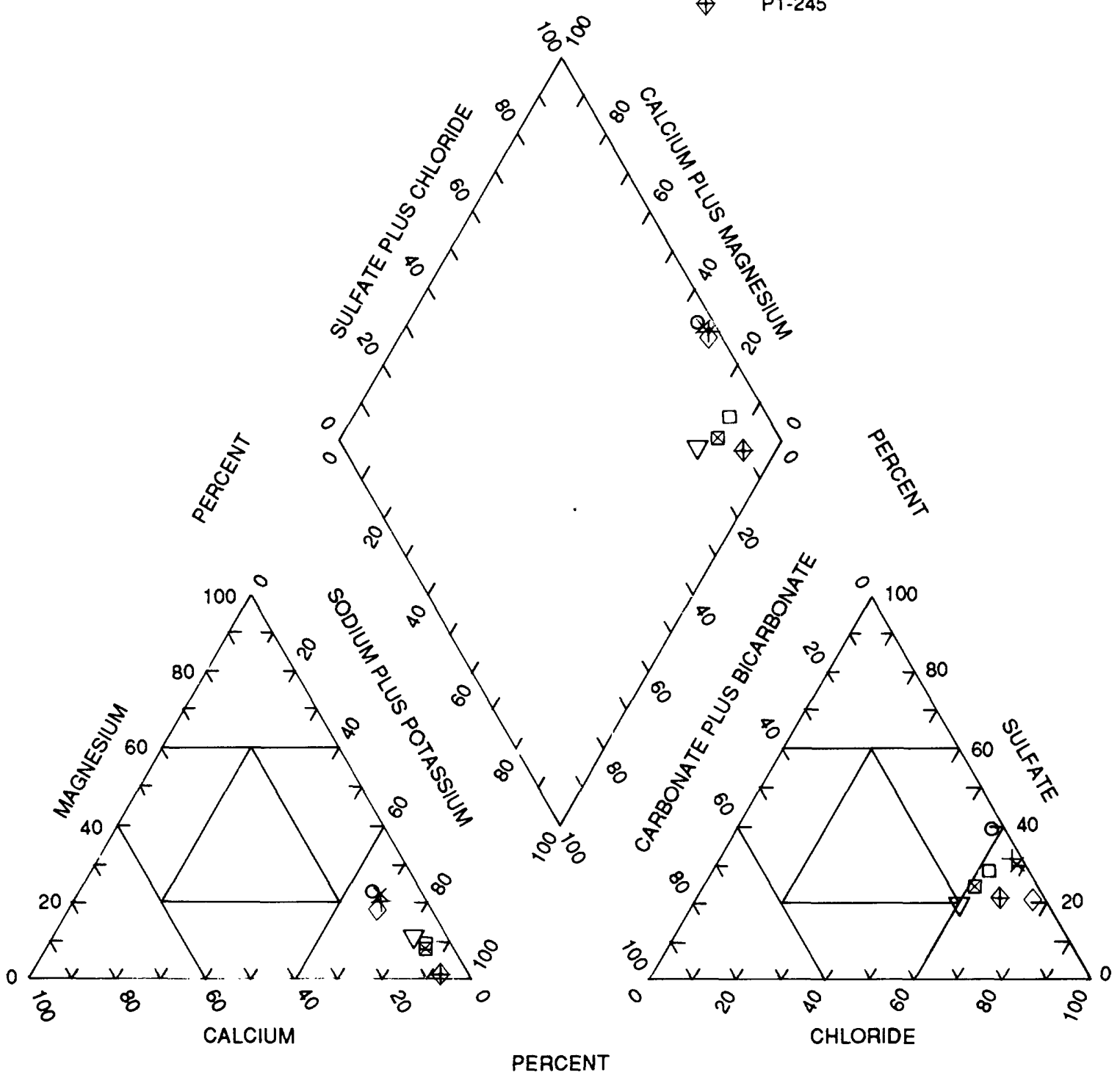

PERCENT

Figure 6. Major-ion chemistry of ground-water samples from observation wells. 
Table 1. Analyses of ground-water samples from obsenvation wells for major constituents and selenium

[Observation well: Number is depth, in feet below land surface to the midpoint of the screened interval of individual well. $\mu \mathrm{S} / \mathrm{cm}$, microsiemen per centimeter. ${ }^{\circ} \mathrm{C}$, degree Celsius; $\mathrm{mg} / \mathrm{L}$, milligram per liter; $\mu \mathrm{g} / \mathrm{L}$, microgram per liter. $<$, actual value is less than value shown]

\begin{tabular}{|c|c|c|c|c|c|c|c|c|}
\hline $\begin{array}{l}\text { Observation } \\
\text { well }\end{array}$ & Date & $\begin{array}{c}\text { Specific } \\
\text { conductance } \\
(\mu \mathrm{S} / \mathrm{cm})\end{array}$ & $\begin{array}{c}\mathrm{pH} \\
\text { (standard } \\
\text { units) }\end{array}$ & $\begin{array}{c}\text { Temperature, } \\
\text { water } \\
\left({ }^{\circ} \mathrm{C}\right)\end{array}$ & $\begin{array}{c}\text { Calcium, } \\
\text { dissolved } \\
(\mathrm{mg} / \mathrm{L})\end{array}$ & $\begin{array}{l}\text { Magnesium, } \\
\text { dissolved } \\
(\mathrm{mg} / \mathrm{L})\end{array}$ & $\begin{array}{c}\text { Sodium, } \\
\text { dissolved } \\
\text { (mg/L) }\end{array}$ & $\begin{array}{c}\text { Potassium, } \\
\text { dissolved } \\
(\mathrm{mg} / \mathrm{L})\end{array}$ \\
\hline P1-24.5 & $4-23-87$ & 11,500 & 7.85 & 21.0 & 130 & 130 & 2,200 & 4.6 \\
\hline P1-32.5 & $4-22-87$ & 17,000 & 6.80 & 21.5 & 410 & 520 & 2,900 & 14 \\
\hline P1-38.7 & $4-22-87$ & 25,600 & 7.12 & 21.5 & 560 & 700 & 4,400 & 17 \\
\hline$P 1-45$ & $4-22-87$ & 28,300 & 7.23 & 21.5 & 580 & 790 & 4,700 & 13 \\
\hline P1-49 & $4-23-87$ & 18,900 & 7.29 & 21.5 & 440 & 450 & 3,100 & 9.8 \\
\hline P1-55 & $4-22-87$ & 3,960 & 8.16 & 23.0 & 53 & 44 & 660 & 3.3 \\
\hline P1-60 & $4-23-87$ & 3,270 & 8.38 & 22.0 & 34 & 30 & 560 & 2.7 \\
\hline P1-245 & $11-20-85$ & 3,840 & 7.87 & 20.5 & 49 & 6.0 & 820 & 5.4 \\
\hline $\begin{array}{l}\text { Observation } \\
\text { well }\end{array}$ & Date & $\begin{array}{c}\text { Alkalinity, } \\
\text { carbonate } \\
(\mathrm{mg} / \mathrm{L} \text { as } \\
\left.\mathrm{CaCO}_{3}\right)\end{array}$ & $\begin{array}{c}\text { Sulfate, } \\
\text { dissolved } \\
(\mathrm{mg} / \mathrm{L})\end{array}$ & $\begin{array}{r}\text { Chlor } \\
\text { disso } \\
\text { (mg }\end{array}$ & & $\begin{array}{l}\text { Silica, } \\
\text { dissolved } \\
(\mathrm{mg} / \mathrm{L})\end{array}$ & $\begin{array}{l}\text { ids, sum of } \\
\text { nstituents, } \\
\text { issolved } \\
\text { (mg/L) }\end{array}$ & $\begin{array}{c}\text { Selenium, } \\
\text { dissolved } \\
(\mu \mathrm{g} / \mathrm{L})\end{array}$ \\
\hline P1-24.5 & 4-23-87 & 528 & 1,600 & 2,6 & & 24 & 7,030 & 480 \\
\hline P1-32.5 & $4-22-87$ & 303 & 3,900 & 4,2 & & 24 & 12,200 & $<1$ \\
\hline P1-38.7 & $4-22-87$ & 362 & 4,600 & 7,2 & & 21 & 17,800 & $<1$ \\
\hline P1-45 & $4-22-87$ & 360 & 5,100 & 8,5 & & 29 & 20,000 & $<1$ \\
\hline P1-49 & 4-23-87 & 300 & 2,100 & 5,6 & & 25 & 11,900 & $<1$ \\
\hline P1-55 & $4-22-87$ & 436 & 390 & & & 30 & 2,360 & $<1$ \\
\hline P1-60 & $4-23-87$ & 224 & 360 & & & 31 & 2,020 & $<1$ \\
\hline P1-245 & $11-20-85$ & 203 & 420 & & & 33 & 2,450 & $<1$ \\
\hline
\end{tabular}

The plot of delta deuterium $(\delta \mathrm{D})$ and $\delta^{18} \mathrm{O}$ for ground water and porewater data show that the well data fall along a best-fit line for ground water in western Fresno County calculated on the basis of more than 300 samples (Davis and Coplen, 1989) (fig. 8). Porewater data from the same depths as the wells are shifted slightly to the right, likely as a result of minimal evaporation during handling of the samples due to their small volume. The enriched samples of porewater from depths equal to or less than $23.5 \mathrm{ft}$ are significantly shifted to the right of the local ground-water line due to evaporation. These samples fall along a straight line that extrapolates back to the position of the deeper ground-water samples, indicating that the shallower evaporative water had an initial isotopic composition similar to that of the deeper water.

Large amounts of evaporation and the accompanying isotopic enrichment usually occur when the water table is close to the land surface. Experimental laboratory studies of evaporation from bare soil observed a maximum evaporation rate of less than $0.5 \mathrm{~mm} / \mathrm{d}$ from a clay soil with a water table depth equal to the minimum depth $(14.5 \mathrm{ft})$ observed at the P1 study site (Gardner and Fireman, 1958). As the depth to the water table at the P1 site has been greater than $14.5 \mathrm{ft}$ and surface conditions are optimal for evaporation only a fraction of the year, the potential annual evaporation is estimated to be less than $50 \mathrm{~mm}$. Although this rate of evaporation is small, it would be sufficient to cause isotopic enrichment at the water table given sufficient time and in the absence of recharge. Alternatively, the isotopically enriched water evolved at a time when the water table was shallower or migrated to the site from an adjacent area with a shallow water table.

Tritium concentrations in ground-water samples collected from wells at a depth of $60 \mathrm{ft}$ or less in 


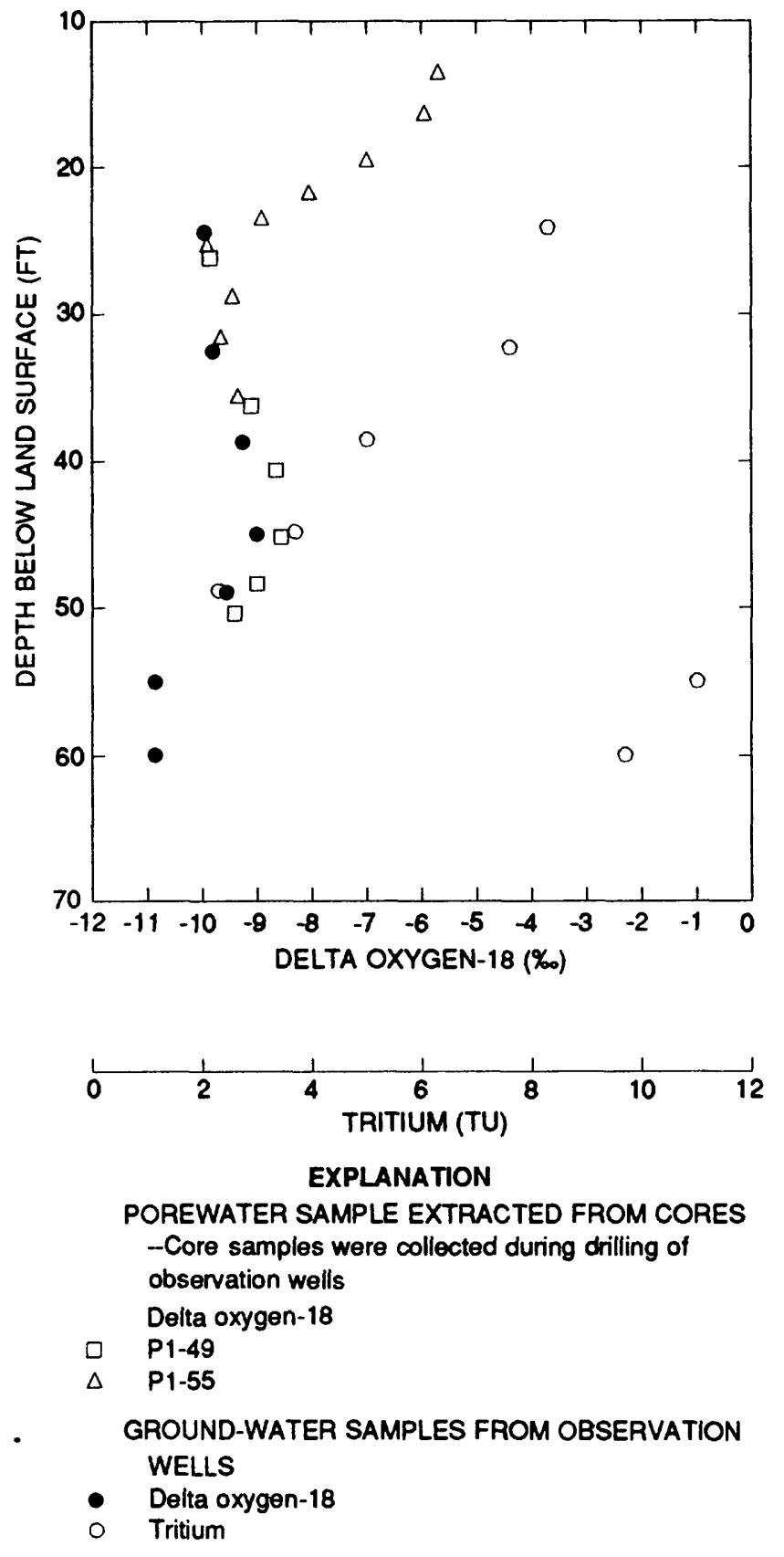

Figure 7. Delta oxygen- 18 ratios in ground-water and porewater samples and tritium concentrations in ground-water samples.

1985 and 1987 range from 2.3 to 11 tritium units (Tu) (fig. 7, table 2). Tritium concentrations decrease from a depth of 24.5 to $49 \mathrm{ft}$ below land surface, but are high $(9.7$ to $11 \mathrm{Tu})$ in ground water at 55 to $60 \mathrm{ft}$. These values indicate that all of these water samples contain some component of water that originated as precipitation after the increase in the tritium concentration of precipitation due to atmospheric testing of
Table 2. Analyses of ground-water samples from observation wells for tritium, delta deuterium, and delta oxygen-18

[Observation well: Number is depth, in feet below land surface to the midpoint of the screened interval of individual well. Tu, tritium units; $\%$, per mil. $<$, actual value is less than value shown]

\begin{tabular}{lcccc}
\hline $\begin{array}{l}\text { Obser- } \\
\text { vation } \\
\text { well }\end{array}$ & Date & $\begin{array}{c}\text { Tritium, } \\
\text { total } \\
(\mathrm{Tu})\end{array}$ & $\begin{array}{c}\text { Delta } \\
\text { deuterium } \\
(\%)\end{array}$ & $\begin{array}{c}\text { Delta } \\
\text { oxygen-18 } \\
(\%)\end{array}$ \\
\hline P1-24.5 & $4-23-87$ & 8.3 & -76.0 & -9.95 \\
P1-32.5 & $4-22-87$ & 7.6 & -76.0 & -9.80 \\
P1-38.7 & $4-22-87$ & 5.0 & -71.5 & -9.25 \\
P1-45 & $4-22-87$ & 3.7 & -72.0 & -9.00 \\
P1-49 & $4-23-87$ & 2.3 & -72.5 & -9.55 \\
P1-55 & $4-22-87$ & 11 & -81.0 & -10.85 \\
P1-60 & $4-23-87$ & 9.7 & -81.5 & -10.85 \\
P1-245 & $11-20-85$ & $<.8$ & -84.5 & -11.10 \\
\hline
\end{tabular}

nuclear weapons which began in 1952 . The sudden increase in tritium from a depth of 49 to $55 \mathrm{ft}$ indicates that water at depths greater than $49 \mathrm{ft}$ is part of a different local flow system with more rapid recharge. This is supported by the rapid change in the dissolved-solids concentration over this depth interval.

The decrease in tritium concentration with depth suggests increasing age, but absolute ages cannot be calculated due to the lack of data on the initial tritium concentrations in precipitation and in the various water used for irrigation in the area. The decrease in tritium concentration with depth may be due to the shift in the primary source of irrigation water from local ground water low in tritium prior to 1967 to canal water high in tritium after 1967. Another possibility is that the decrease in tritium concentration from a depth of about 24 to $49 \mathrm{ft}$ could reflect the decrease in the concentration of tritium present in precipitation from 1963 to 1952 . Alternately, young water that has moved downward through the more permeable zones of the profile may have lost tritium due to diffusion into clay lenses containing older water. This also would result in a gradual decrease in the tritium concentration with increasing depth. This phenomena has been observed in other geologic settings where interbedding with large permeability contrasts occur and in dual-porosity systems (Grisak and Pickens, 1980; Desaulniers and others, 1981; Sudicky and Frind, 1981). Regardless of the uncertainty as to the exact mechanism responsible for the tritium concentration profile, all of the proposed processes invoke increasing age from a depth of 24 to $60 \mathrm{ft}$. 
Table 3. Geochemical data for porewater samples from cores P1-55 and P1-49, April 1987; and P1-63, August 9-10, 1988

[ft, feet; $\mu \mathrm{S} / \mathrm{cm}$, microsiemen per centimeter; $\mu \mathrm{g} / \mathrm{L}$, microgram per liter; $\%$, per mil; --, no data. <, actual value is less than value shown]

\begin{tabular}{|c|c|c|c|c|c|c|c|}
\hline \multicolumn{3}{|c|}{$\begin{array}{c}\text { Interval sampled } \\
\text { (ft) }\end{array}$} & \multirow{2}{*}{$\begin{array}{c}\text { Specific } \\
\text { conductance } \\
(\mu \mathrm{S} / \mathrm{cm})\end{array}$} & \multirow{2}{*}{$\begin{array}{c}\text { Manganese } \\
(\mu \mathrm{g} / \mathrm{L})\end{array}$} & \multirow{2}{*}{$\begin{array}{l}\text { Selenium } \\
(\mu \mathrm{g} / \mathrm{L})\end{array}$} & \multirow{2}{*}{$\begin{array}{c}\text { Delta } \\
\text { deuterium } \\
(\%)\end{array}$} & \multirow{2}{*}{$\begin{array}{c}\text { Delta } \\
\text { oxygen-18 } \\
(\% 0)\end{array}$} \\
\hline Midpoint & Top & Bottom & & & & & \\
\hline \multicolumn{8}{|c|}{ Core P1-55, April 1987} \\
\hline 13.5 & 13.0 & 14.0 & 18,500 & -- & 10 & -54.7 & -5.70 \\
\hline 14.8 & 14.0 & 15.7 & 14,700 & -- & 13 & -- &.- \\
\hline 15.5 & 15.0 & 16.0 & 14,900 & 60 & 21 & -- & -. \\
\hline 16.4 & 16.0 & 16.8 & 15,200 & -- & 31 & -56.0 & -5.95 \\
\hline 17.4 & 16.8 & 18.0 & 15,300 & 66 & 73 & -. & -. \\
\hline 18.5 & 18.0 & 19.0 & 15,600 & -- & 174 & -- & -- \\
\hline 19.5 & 19.0 & 20.0 & 16,200 & -- & 487 & -61.0 & -7.00 \\
\hline 20.5 & 20.0 & 21.0 & 16,400 & 60 & 918 & -. & -. \\
\hline 21.8 & 21.5 & 22.0 & 14,400 & -- & 1,240 & -67.5 & -8.05 \\
\hline 22.5 & 22.0 & 23.0 & 14,200 & 24 & 1,520 & -- & -. \\
\hline 23.5 & 23.0 & 24.0 & 12,600 & - & 967 & -72.5 & -8.90 \\
\hline 24.3 & 24.0 & 24.6 & 10,700 & -- & 358 & -- & -- \\
\hline 25.3 & 24.6 & 25.9 & 9,400 & 154 & 33 & -77.0 & -9.90 \\
\hline 26.2 & 25.9 & 26.5 & -- & -- & -- & -- & -. \\
\hline 26.3 & 26.0 & 26.5 & -- & -- & 196 & -- & -- \\
\hline 27 & -. & -. & 10,800 & -. & -. & -- & -. \\
\hline 28.0 & 27.5 & 28.5 & -- & -- & 107 & -- & -- \\
\hline 28.8 & 28.5 & 29.0 & 12,000 & -- & 26 & -75.5 & -9.45 \\
\hline 29 & -- & -- & 10,900 & -- & -- & -- & -- \\
\hline 29.5 & 29.0 & 30.0 & 11,900 & 1,460 & 93 & -- & -- \\
\hline 30.5 & 30.0 & 31.0 & 12,300 & -- & 79 & -. & -- \\
\hline 31 & -- & -- & 11,600 & -- & .. & .- & -. \\
\hline 31.5 & 31.0 & 32.0 & 13,400 & 2,200 & 4.0 & -76.0 & -9.65 \\
\hline 34.1 & -- & -- & 18,300 & -- & -- & -- & -- \\
\hline 35.5 & 35.0 & 36.0 & 18,500 & -- & 13 & -73.5 & -9.35 \\
\hline 36.2 & -- & -- & 19,400 & -- & - & - & -- \\
\hline 36.7 & 36.6 & 36.8 & 25,900 & .- & -. & -- & -- \\
\hline 42.1 & 42.0 & 42.2 & 24,500 & -- & -- & -- & -- \\
\hline 43.9 & 43.8 & 44.0 & 21,200 & -. & -. & -- & -. \\
\hline 47.6 & 47.4 & 47.7 & 19,800 & -- & -- & -- & -- \\
\hline 48.5 & 48.0 & 49.0 & 17,200 & -- & -- & -- & - \\
\hline 52.1 & 51.8 & 52.4 & 15,400 & -. & .- & -. & -. \\
\hline 52.6 & 52.4 & 52.7 & 15,000 & -- & -- & -- & -- \\
\hline 53.6 & 53.4 & 53.7 & 8,780 & -- & .- & -. & .- \\
\hline 56.1 & 55.4 & 56.8 & 7,040 & - & -- & -- & -- \\
\hline \multicolumn{8}{|c|}{ Core P1-49, April 1987} \\
\hline 21.6 & 21.4 & 21.7 & 16,300 & -- & 1,410 & - & -- \\
\hline 24.1 & 24.0 & 24.2 & 10.600 & -- & 412 & -- & .- \\
\hline 24.6 & 24.2 & 25.0 & 10.700 & 146 & 190 & .- & -- \\
\hline 26.2 & 25.9 & 26.5 & 10,400 & 220 & 181 & -77.5 & -9.85 \\
\hline 26.6 & 26.5 & 26.7 & 11,000 & -- & 104 & -- &.- \\
\hline 29.8 & 28.0 & 31.5 & 10,900 & -. & 29 & -. & -. \\
\hline 31.5 & -. & -- & 14,400 & -- & 73 & -. & -. \\
\hline 31.6 & 31.5 & 31.7 & 13,200 & -- & 9 & -- & -- \\
\hline 32.8 & 31.7 & 34.0 & 15,400 & - & 23 & - & -- \\
\hline 34.1 & 34.0 & 34.2 & 16,200 & -- & 20 & .- & -- \\
\hline 36.2 & 35.9 & 36.4 & 20,800 & 8,000 & 13 & -72.0 & -9.10 \\
\hline
\end{tabular}


Table 3. Geochemical data for porewater samples from cores P1-55 and P1-49. April 1987; and P1-63. August 9-10, 1988--Continued

\begin{tabular}{|c|c|c|c|c|c|c|c|}
\hline \multicolumn{3}{|c|}{$\begin{array}{l}\text { Intervál sampled } \\
(\mathrm{ft})\end{array}$} & \multirow{2}{*}{$\begin{array}{c}\text { Specific } \\
\text { conductance } \\
(\mu \mathrm{S} / \mathrm{cm})\end{array}$} & \multirow{2}{*}{$\begin{array}{l}\text { Manganese } \\
(\mu \mathrm{g} / \mathrm{L})\end{array}$} & \multirow{2}{*}{$\begin{array}{l}\text { Selenium } \\
(\mu \mathrm{g} / \mathrm{L})\end{array}$} & \multirow{2}{*}{$\begin{array}{c}\text { Delta } \\
\text { deuterium } \\
(\%)\end{array}$} & \multirow{2}{*}{$\begin{array}{c}\text { Delta } \\
\text { oxygen-18 } \\
(\%)\end{array}$} \\
\hline Midpoint & Top & Bottom & & & & & \\
\hline \multicolumn{8}{|c|}{ Core P1-49, April 1987--Continued } \\
\hline 36.5 & 36.4 & 36.6 & 24,500 & -- & 12 & -- & -- \\
\hline 38.8 & 38.4 & 39.2 & 22,100 & 3,700 & 8.9 & -- & -- \\
\hline 40.6 & 40.2 & 41.0 & 23,300 & -- & 2.0 & -70.0 & -8.65 \\
\hline 41.2 & 41.0 & 41.5 & 22,800 & -- & 2.0 & -- & -- \\
\hline 43.4 & 43.0 & 43.8 & 23,400 & -- & 12 & -- & -- \\
\hline 43.9 & 43.8 & 44.0 & 23,000 & -- & 5.0 & -- & -- \\
\hline 45.2 & 44.8 & 45.5 & 22,300 & -- & 2.4 & -70.5 & -8.55 \\
\hline 46.4 & 46.3 & 46.5 & 21,100 & -- & 5.0 & -. & -- \\
\hline 46.8 & 46.5 & 47.2 & 22,000 & -- & 6.1 & -- & -- \\
\hline 48.4 & 48.0 & 48.8 & 20,900 & 1,104 & 1.9 & -72.5 & -9.00 \\
\hline 48.9 & 48.8 & 49.0 & 17,400 & -- & 3.0 & -- & -- \\
\hline 50.4 & 50.0 & 50.8 & 17,800 & -- & $<.1$ & -75.0 & -9.40 \\
\hline \multirow[t]{33}{*}{50.9} & 50.8 & 51.0 & 15,900 & -- & 2.0 & -- & -- \\
\hline & \multicolumn{3}{|c|}{$\begin{array}{c}\text { Interval sampled } \\
\text { (ft) }\end{array}$} & \multirow{2}{*}{$\begin{array}{c}\text { Specific } \\
\text { conductance } \\
(\mu \mathrm{S} / \mathrm{cm})\end{array}$} & \multirow{2}{*}{$\begin{array}{c}\text { Manganese } \\
(\mu \mathrm{g} / \mathrm{L})\end{array}$} & \multirow{2}{*}{$\begin{array}{c}\text { Selenium } \\
(\mu \mathrm{g} / \mathrm{L})\end{array}$} & \\
\hline & Midpoint & Top & Bottom & & & & \\
\hline & \multicolumn{6}{|c|}{ Core P1-63, August 9-10, 1988} & \\
\hline & 12.8 & 12.4 & 13.4 & 18,600 & -. & -- & \\
\hline & 14.0 & 13.5 & 14.5 & 15,200 & 35 & 14.0 & \\
\hline & 15.0 & 14.5 & 15.5 & 12,500 & -. & -- & \\
\hline & 16.0 & 15.5 & 16.5 & 12,400 & -- & -. & \\
\hline & 16.9 & 16.6 & 17.2 & 15,300 & 59 & 116.0 & \\
\hline & 17.8 & 17.2 & 18.2 & 15,600 & 120 & 207.0 & \\
\hline & 18.8 & 18.2 & 19.2 & 15,300 & 66 & 682.0 & \\
\hline & 19.9 & 19.4 & 20.4 & 16,400 & 79 & 962.0 & \\
\hline & 20.9 & 20.4 & 21.4 & 16,200 & 51 & $1,440.0$ & \\
\hline & 21.9 & 21.4 & 22.4 & 18,200 & 44 & $1,200.0$ & \\
\hline & 22.9 & 22.4 & 23.4 & 15,000 & 41 & $1,510.0$ & \\
\hline & 23.7 & 23.2 & 24.2 & 13,700 & 53 & $1,030.0$ & \\
\hline & 24.7 & 24.2 & 25.2 & 12,400 & -- & $1,100.0$ & \\
\hline & 25.6 & 25.4 & 25.7 & 12,400 & 520 & 488.0 & \\
\hline & 26.2 & 25.7 & 26.7 & 12,400 & -- & 370.0 & \\
\hline & 27.2 & 26.7 & 27.7 & 14,200 & 190 & 121.0 & \\
\hline & 28.6 & 28.4 & 28.8 & 13,300 & 3,300 & 9.0 & \\
\hline & 29.3 & 28.8 & 29.8 & 12,900 & -. & 5.0 & \\
\hline & 30.9 & 30.4 & 31.4 & 12,500 & 3,800 & 20.0 & \\
\hline & 31.9 & 31.4 & 32.4 & 12,300 & -- & 2.0 & \\
\hline & 32.9 & 32.4 & 33.4 & 14,300 & 9,600 & 1.7 & \\
\hline & 33.9 & 33.4 & 34.4 & 16,700 & 10,000 & .2 & \\
\hline & 34.9 & 34.4 & 35.4 & 16,000 & 14,000 & 1.0 & \\
\hline & 35.9 & 35.4 & 36.4 & 19,100 & 13,000 & 1.5 & \\
\hline & 36.2 & 36.0 & 36.4 & 18,200 & 12,000 & 1.8 & \\
\hline & 43.0 & 42.7 & 43.2 & 27,100 & -- & .1 & \\
\hline & 43.7 & 43.2 & 44.2 & 25,700 & 2,700 & 1.8 & \\
\hline & 44.8 & 44.4 & 45.2 & 27,100 & 5,500 & 2.5 & \\
\hline & 45.7 & 45.2 & 46.2 & 24,500 & 2,700 & $<.1$ & \\
\hline
\end{tabular}




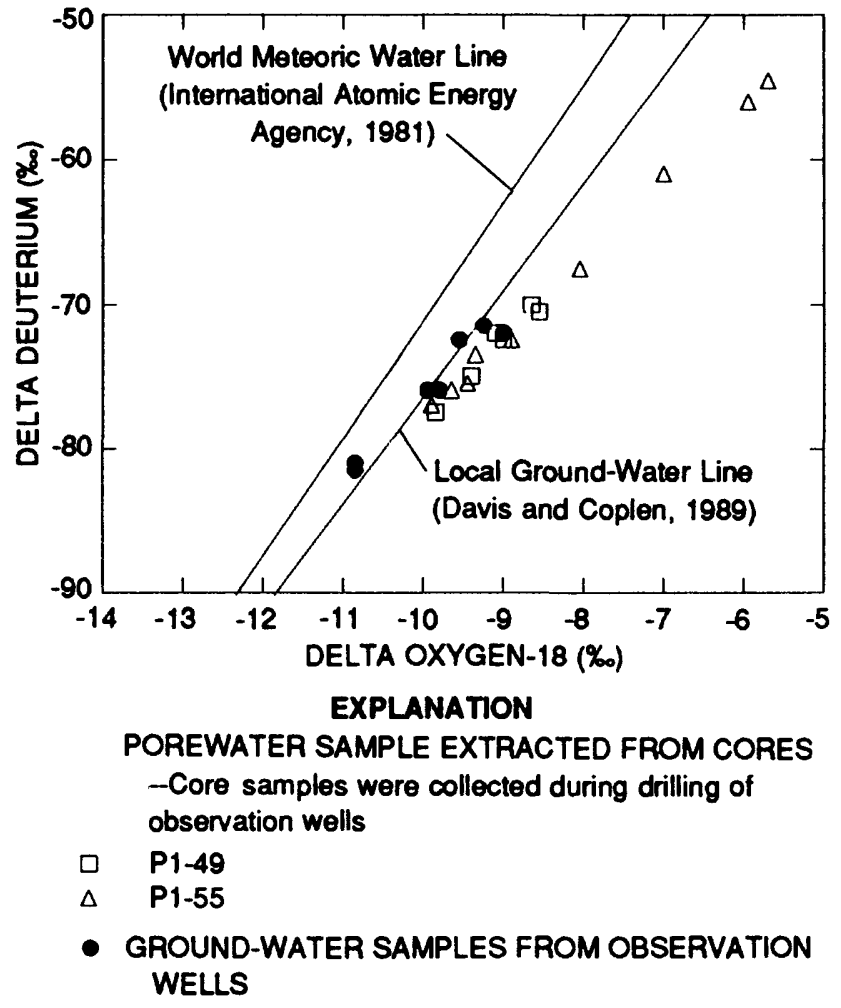

Figure 8. Delta deuterium and delta oxygen-18 for ground-water and porewater samples.

The following model for the origin of the ground water at the study site can be constructed based on the hydrologic, stable-isotope, and tritium data.

1. Under natural conditions prior to irrigation and ground-water development, the site was a discharge area for regional ground-water flow from the Panoche Creek alluvial fan. Saline soil conditions evolved due to evaporative concentration of ground water from a shallow water table.

2. During the period in which the water table was drawn down due to extensive pumpage, the site was not directly irrigated and recharge to the water table was by lateral flow from adjacent irrigated areas and municipal water use.

3. At the time during which the ground water presently between about 25 and $50 \mathrm{ft}$ below land surface was recharged, the water table in the contributing areas must have been sufficiently deep to limit evaporation from the water table, as indicated by the lack of isotopic enrichment in water from these depths. The high dissolved-solids concentration in this zone must therefore be due to leaching of preexisting soil salts.
4. Following the introduction of surface water, ground-water pumpage decreased and the water-table altitude in the area contributing recharge to the site increased to within several feet of the surface and was subject to evaporative concentration.

\section{DISTRIBUTION OF SELENIUM}

Analyses of ground-water samples from the first wells installed at the site showed a total selenium concentration of $480 \mu \mathrm{g} / \mathrm{L}$ at a depth of $24.5 \mathrm{ft}$ and a selenium concentration of less than $1 \mu \mathrm{g} / \mathrm{L}$ at $60 \mathrm{ft}$. Data on ground-water chemistry at other locations in the Coast Range alluvial fans of the San Joaquin Valley showed that the logarithms of selenium concentration and specific conductance are highly correlated (Deverel and Fujii, 1988; Deverel and Millard, 1988). Specific conductance was used as a predictor for selenium concentration so that screened intervals of additional wells would provide the best definition of the depth distribution of selenium concentrations in the ground water. Wells at depths of $32.5,38.7,45,49$, and $55 \mathrm{ft}$ below land surface were situated to sample ground water representing the entire range of the specific conductance values measured on porewater extracted in the field.

Selenium concentrations in all samples of ground water from wells screened at depths of $32.5 \mathrm{ft}$ or greater were less than the detection limit of $1 \mu \mathrm{g} / \mathrm{L}$ (table 1). Selenium analyses for porewater that was hydraulically extracted from undisturbed cores showed that concentrations of total selenium are extremely high in a narrow, sharply bounded zone with a peak concentration at a depth of 20.9 to $24.7 \mathrm{ft}$ (fig. 9, table 3). Selenium concentration profiles were similar in all three cores taken at the site with maximum concentrations of $1,520 \mu \mathrm{g} / \mathrm{L}$ at $22.5 \mathrm{ft}$ in core P1-55, $1,410 \mu \mathrm{g} / \mathrm{L}$ at $21.56 \mathrm{ft}$ in core $\mathrm{P} 1-49$, and $1,510 \mu \mathrm{g} / \mathrm{L}$ at $22.9 \mathrm{ft}$ in core P1-63 (fig. 9). Selenium concentrations decrease rapidly to less than $100 \mu \mathrm{g} / \mathrm{L}$ at depths of greater than about $28 \mathrm{ft}$ and at depths of less than $18 \mathrm{ft}$. Selenium concentrations in porewater from depths greater than $30 \mathrm{ft}$ below land surface are low, but almost always greater than the detection limit. The presence of detectable selenium in porewater samples extracted from depths at which no selenium was detected in the well samples may be the result of mobilization of adsorbed selenium due to the applied pressure (less than 2,000 lb/in ${ }^{2}$ ) (Manheim, 1966) or the solubilization of small amounts of reduced selenium minerals due to oxidation during sample preparation. 


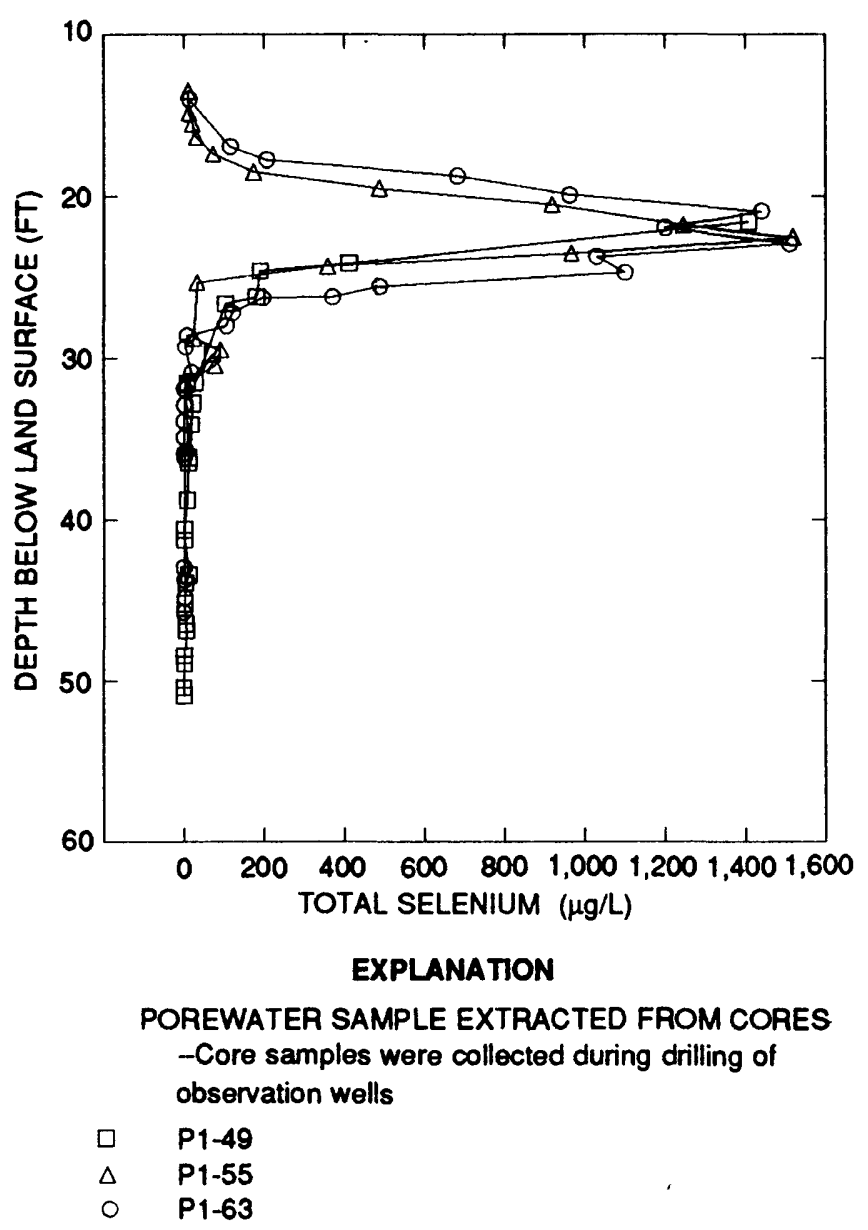

Figure 9. Selenium concentrations in porewater samples.

Analysis of selenium species showed that essentially all of the selenium in solution is hexavalent selenate $\left(\mathrm{SeO}_{4}^{2-}\right)$. The concentration of tetravalent selenite $\left(\mathrm{SeO}_{3}^{2-}\right)$ was less than $1 \mu \mathrm{g} / \mathrm{L}$ in all of the ground-water samples from wells except for the sample from $24.5 \mathrm{ft}$. This sample contained $19 \mu \mathrm{g} / \mathrm{L}$ of selenite, which constituted 4 percent of the total selenium present in the sample. The sample from a depth of $27.2 \mathrm{ft}$ in the P1-63 core was the only porewater sample that contained a measurable, though small $(9 \mu \mathrm{g} / \mathrm{L})$, amount of selenite.

Along with the specific conductance data, the similarity of the selenium concentration profiles in the three cores indicate that the vertical chemical distribution pattern is consistent in porewaters at sites 10 to $20 \mathrm{ft}$ apart. Furthermore, the water table was at a depth of $27.6 \mathrm{ft}$, or $10 \mathrm{ft}$ deeper, when the August 1988 cores were taken than when the April 1987 cores were taken. Most of the porewaters with high selenium concentrations in the 1988 profile are in fact above the water table at the time of sampling, and the similarities between the 1987 and 1988 profiles for specific conductance and selenium concentration indicate little actual movement of water in spite of the large change in hydraulic head. This likely is due to the high field capacity of the fine-grained sediments in the upper part of the stratigraphy. It seems that short-term seasonal fluctuations in water levels do not result in much solute movement.

Fluctuations in the depth to the water table will, however, affect the depth of penetration of atmospheric oxygen and, hence, the depth of oxidizing conditions in the sediments. Evidence of this is the mottling of the sediments described previously from a depth of 14 to $24 \mathrm{ft}$. The peak selenium concentrations occur in this zone, indicating that changes in redox potential, possibly related to water-table fluctuations, influence the location of high selenium concentrations in ground water.

The most notable feature of the selenium data is that, unlike the ground-water chemistry in other areas on Coast Range alluvial-fan deposits, the concentration of selenium is not correlated with specific conductance or the dominant anions, chloride and sulfate, in ground water. The lack of correlation indicates that processes other than leaching of preexisting soil salts and evaporative concentration are controlling the distribution of selenium in ground water at this site.

The solubilities of selenate minerals generally are high (Elrashadi and others, 1987). The concentration of selenium in oxidizing ground water in the western San Joaquin Valley is not limited by solid phase solubility control by a discrete selenium solid phase. For example, although selenium concentrations of several parts per million occur in sodium and magnesium sulfate evaporite minerals currently precipitating from saline seeps in the Coast Range west of the study area, no selenate minerals were identified in these deposits (Presser and others, 1990). In shallow ground water in the western San Joaquin Valley, selenium concentrations are high where solutes are leached from saline soils, and concentrations increase further in areas where evapotranspiration from a shallow water table causes a general increase in solute concentration.

The solubilities of the reduced forms, elemental selcnium $\left(\mathrm{Se}^{0}\right)$ and selenide $\left(\mathrm{Se}^{2-}\right)$, are low (Elrashadi and others, 1987), and the mobility of selenite $\left(\mathrm{SeO}_{3}^{2-}\right)$ is severely limited by adsorption (Balistrieri and 
Chao, 1987; Neal and others, 1987a, 1987b; Goldberg and Glaubig, 1988). The tendency for selenium to be removed from ground water by reduction of selenate to a less soluble form has been recognized in various geologic settings (Harshman, 1972; Masscheleyn and others, 1989; Oremland and others, 1989; Weres and others, 1989). Most pertinently, work done by researchers from Lawrence Berkeley Laboratory at Kesterson Reservoir has shown that although there was widespread infiltration of agricultural drain water into the aquifer underlying the evaporation pond, selenium only entered the aquifer in zones where the ground water remained oxidizing (White, 1988). These field observations, which have been confirmed by laboratory column experiments (Lawrence Berkeley Laboratory, 1987) and in situ injection tests (Benson and others, 1988; Lawrence Berkeley Laboratory, 1988) indicate that the redox potential of the ground water strongly influences the mobility of selenium in ground water in the western San Joaquin Valley.

\section{INFLUENCE OF REDOX POTENTIAL ON SELENIUM DISTRIBUTION}

Ground-water redox potential is difficult to assess quantitatively and apparent redox disequilibrium often occurs in ground water due to (1) chemical and/or biological kinetics, (2) mixed potentials because different redox couples are not at thermodynamic equilibrium, and (3) precipitation or oxidation reactions at the platinum electrode surface (Langmuir, 1971; Whitfield, 1974; Stumm and Morgan, 1981, p. 490; Bricker, 1982; Thorstenson, 1984). Measured relative abundances of redox-sensitive species, therefore, often do not correspond to speciation predicted from thermodynamic calculations using platinum electrode potentials (Lindberg and Runnells, 1984). Measured speciation of an element, however, is useful for predicting solid phase solubility and sorption behavior. The redox potential of the ground water at the site was assessed on the basis of platinum electrode measurements and the abundance of several dissolved constituents which are sensitive to redox conditions.

The most reliable platinum electrode potential measurements were made by pumping ground-water samples from wells through a flow-through cell that excludes atmospheric contamination. Measurements show a maximum of $391 \mathrm{mV}$ at $24.5 \mathrm{ft}$ and decreasing values with depth to a minimum of $66 \mathrm{mV}$ at $55 \mathrm{ft}$ (table 4, fig. 10). Values measured on porewaters extracted under a nitrogen atmosphere were consistently higher and likely were affected by contamination with small amounts of atmospheric oxygen during sample handling.

Dissolved oxygen and nitrate in ground water are electron acceptors and hence usually indicative of oxidizing conditions. The dissolved-oxygen concentration of ground water at the site, measured using a flow-through cell, was less than $1 \mathrm{mg} / \mathrm{L}$ in all wells except the shallowest well at $24.5 \mathrm{ft}$ (table 4). The dissolved-oxygen concentration in this well ranged from 0.2 to $7.9 \mathrm{mg} / \mathrm{L}$ for the five measurements made between April 1986 and February 1988. Measured

Table 4. Indicators of redox potential for ground-water samples from wells

[Observation well: Number is depth, in feet below land surface to the midpoint of the screened interval of individual well. $\mathrm{mV}$, millivolt; $\mathrm{mg} / \mathrm{L}$, milligram per liter; $\mu \mathrm{g} / \mathrm{L}$, microgram per liter. <, actual value is less than value shown]

\begin{tabular}{lccccrr}
\hline $\begin{array}{c}\text { Observation } \\
\text { well }\end{array}$ & Date & $\begin{array}{c}\text { Eh } \\
(\mathrm{mV})\end{array}$ & $\begin{array}{c}\text { Dissolved } \\
\text { oxygen } \\
(\mathrm{mg} / \mathrm{L})\end{array}$ & $\begin{array}{c}\text { Nitrate } \\
(\mathrm{mg} / \mathrm{L} \text { as } \mathrm{N})\end{array}$ & $\begin{array}{c}\text { Iron } \\
(\mu \mathrm{g} / \mathrm{L})\end{array}$ & $\begin{array}{c}\text { Manganese } \\
(\mu \mathrm{g} / \mathrm{L})\end{array}$ \\
\hline P1-24.5 & $4-23-87$ & 391 & 0.2 & 1.5 & 20 & 450 \\
P1-32.5 & $4-22-87$ & 203 & .3 & $<.1$ & 11,000 & 12,000 \\
P1-38.7 & $4-22-87$ & 170 & .2 & $<.1$ & 10,000 & 12,000 \\
P1-45 & $4-22-87$ & 130 & .2 & $<.1$ & 14,000 & 11,000 \\
P1-49 & $4-23-87$ & 136 & .2 & $<.1$ & 1,600 & 4,100 \\
P1-55 & $4-22-87$ & 66 & .2 & $<.1$ & 100 & 180 \\
P1-60 & $4-23-87$ & 97 & .2 & $<.1$ & 250 & 210 \\
\hline
\end{tabular}




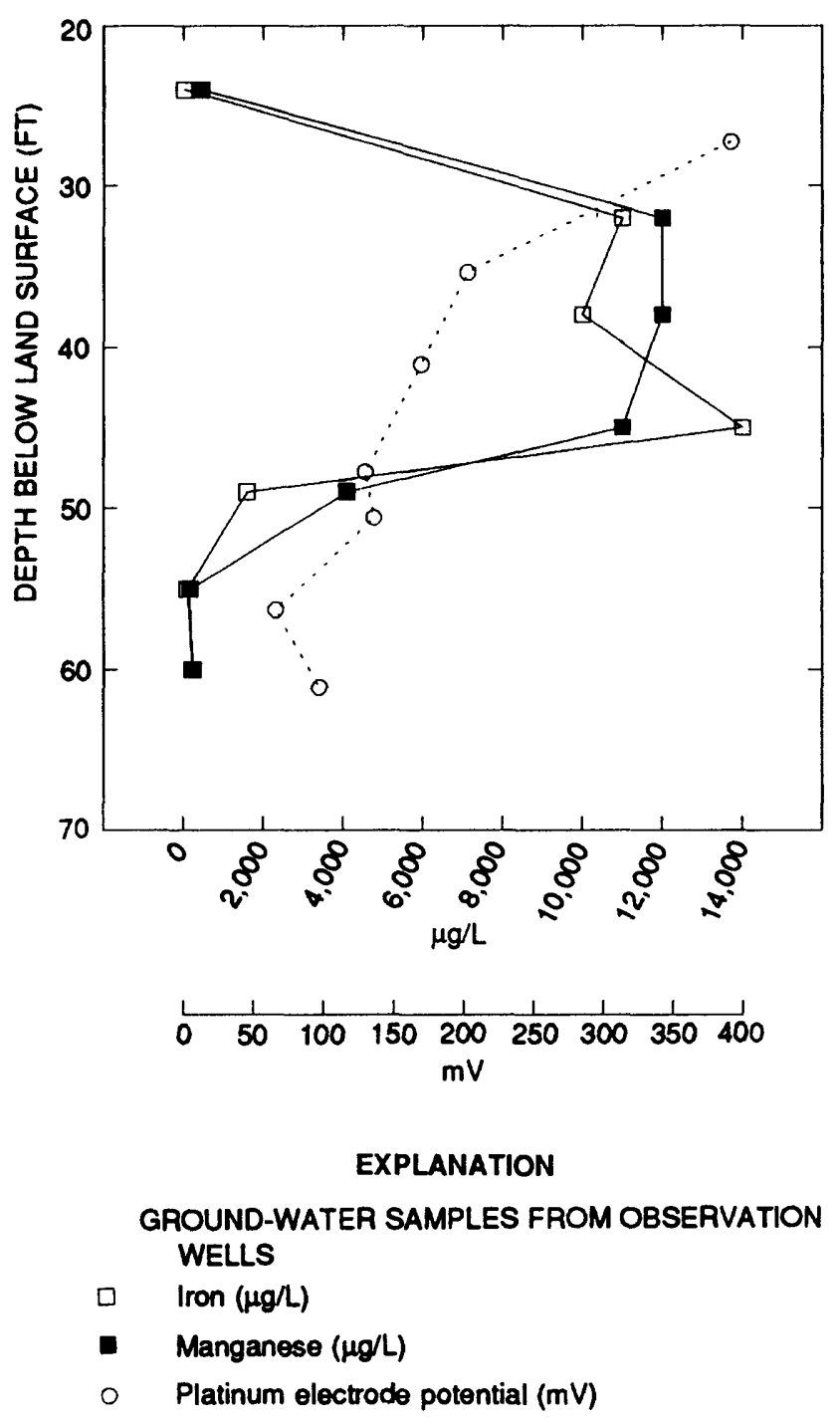

Figure 10. Platinum electrode redox potential and concentrations of iron and manganese in ground-water samples.

values in the deeper wells range from 0.2 to $0.3 \mathrm{mg} / \mathrm{L}$; however, these values are near the detection limit and most of the ground water at the site likely has a dissolved-oxygen concentration of $0.1 \mathrm{mg} / \mathrm{L}$ or less. Similarly, nitrate concentrations were less than the detection limit of $0.1 \mathrm{mg} / \mathrm{L}$ in all wells except for the shallowest well, which had 1.00 to $1.5 \mathrm{mg} / \mathrm{L}$ in the six samples analyzed between 1985 and 1988. Nitrate concentrations for porewater samples taken above the water table in August 1988 (P1-63) show a maximum concentration of $19.5 \mathrm{mg} / \mathrm{L}$ at $11.4 \mathrm{ft}, 5.98 \mathrm{mg} / \mathrm{L}$ at $12.4 \mathrm{ft}$, and less than $5 \mathrm{mg} / \mathrm{L}$ at $15.5 \mathrm{ft}$ and deeper. The dissolved-oxygen and nitrate data indicate that the ground water is oxidizing above the water table but becomes depleted in these electron-acceptors several $\mathrm{ft}$ below the water table.

The concentration of iron and manganese in oxidizing, near-neutral solutions is limited by the low solubilities of the oxyhydroxides of the oxidized species $\left(\mathrm{Fe}^{+3}\right.$ and $\left.\mathrm{Mn}^{+4}\right)$ of these two metals. The more reduced, divalent forms of iron and manganese have relatively high solubilities, and therefore the presence of iron and manganese is a good indicator of a reducing redox potential. The concentrations of iron in ground-water samples show an almost three order of magnitude increase from $20 \mu \mathrm{g} / \mathrm{L}$ at a depth of $24.5 \mathrm{ft}$ to a maximum of $14,000 \mu \mathrm{g} / \mathrm{L}$ at $45 \mathrm{ft}$ (table 4, fig. 10). The vertical distribution of manganese is similar, with a minimum concentration of $450 \mu \mathrm{g} / \mathrm{L}$ at the 24.5 -foot depth and a maximum concentration of $12,000 \mu \mathrm{g} / \mathrm{L}$ at the 32.5 - and 38.7-foot depth (table 4, fig. 10). The high concentrations of iron and manganese in ground water at depths equal to or greater than $32 \mathrm{ft}$ indicate that the ground water in this interval is moderately reducing. Decreasing concentrations at depths greater than $50 \mathrm{ft}$ are due to mixing with more dilute water (fig. 5). The location of the transition from oxidizing to reducing conditions is defined even more clearly by the profile of manganese concentration in porewater samples (table 3). The porewater data show that manganese concentrations begin to increase at depths greater than $24.6 \mathrm{ft}$ below land surface then rise rapidly at about $30 \mathrm{ft}$ (fig. 11).

In summary, high concentrations of nitrate above the water table indicate that oxidizing conditions dominate in the unsaturated zone. Just below the water table, both nitrate and dissolved oxygen disappear from solution, and the ground water becomes moderately reducing, as indicated by the high concentrations of iron and manganese. This pattern is consistent with the decrease in platinum electrode redox potential with increased depth below the water table. The relation between the concentration of selenium and the redox potential of the ground water can be seen by overlaying the profiles of the selenium and manganese analyses (fig. 11). The data show that the selenium concentration decreases rapidly at the same depth at which manganese concentrations increase, strongly indicating that the decrease in selenium is due to a process that occurs under reducing conditions. 


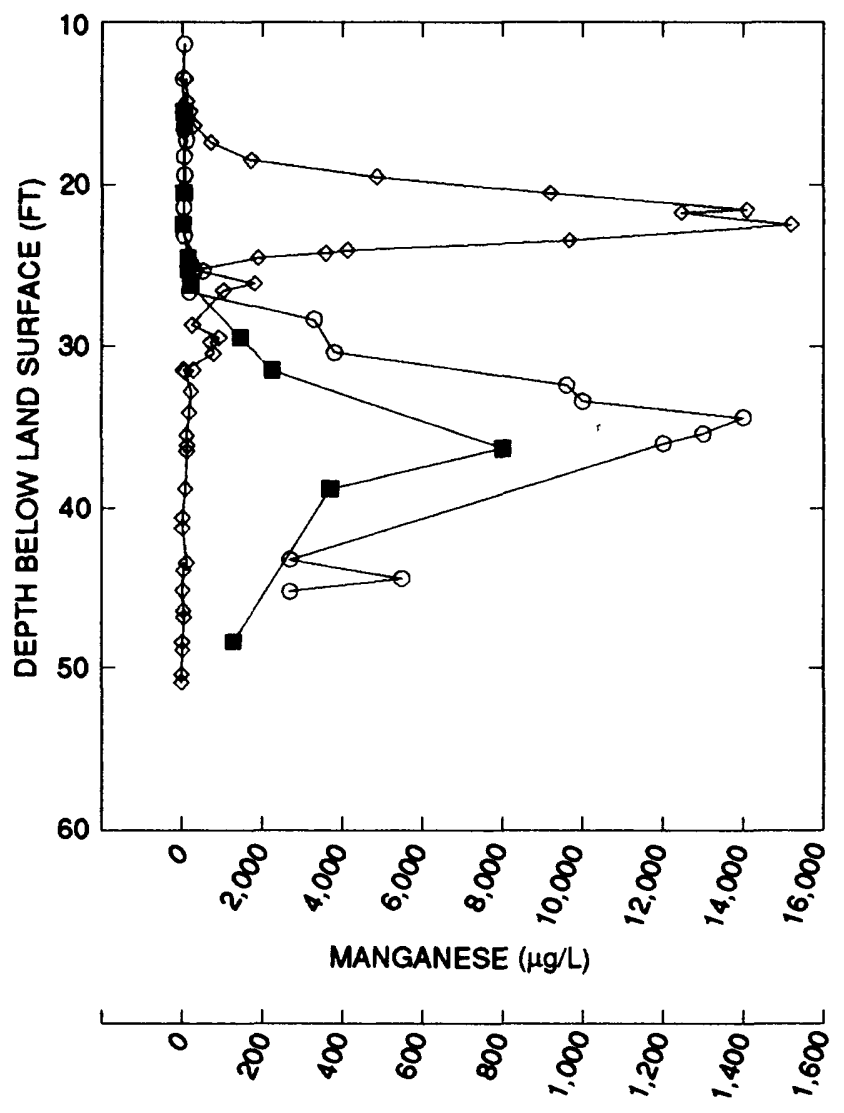

SELENIUM ( $\mu g / L)$

EXPLANATION

POREWATER SAMPLE EXTRACTED FROM CORES -Core samples were collected during drilling of observation wells

- Manganese, $P 1-49$ and P1-55, 1987
Manganese, P1-63, 1988
$\circ \quad$ Selenium, P1-49 and P1-55, 1987

Figure 11. Concentration of manganese in porewater samples from 1987 (P1-55 and P1-49) and 1988 (P1-63). Selenium concentrations in porewater samples from 1987 cores also are shown.

The respiratory reduction of selenate to elemental selenium is a process mediated by anaerobic bacteria (Macy and others, 1989; Oremland and others, 1989). Therefore, the presence of this bacterial activity in selected subsurface sediments from the study site was evaluated. This was achieved by measuring loss of ${ }^{75}$ Se-selenate from solution in samples of slurried core materials. This basic approach was previously used to measure selenate reduction in estuarine sediments (Oremland and others, 1989). Core material (P1-37) was stored at approximatcly $5^{\circ} \mathrm{C}$ for 17 days before processing. Core sections were subsampled
(5-8 samples/section) with 3 cc plastic syringes (hub-end removed), which were sealed with rubber stoppers (size 000). Samples were extruded into serum bottles $(25 \mathrm{~mL})$ under a flow of $\mathrm{N}_{2}$ and mixed with $3 \mathrm{~mL}$ of 50 percent $\mathrm{ABW}$ solution (salinity = about $10 \mathrm{~g} / \mathrm{L} ; \mathrm{pH}=7.3$; Oremland and Polcin, 1982). The serum bottles were sealed under $\mathrm{N}_{2}$ and injected with a deoxygenated stock solution of ${ }^{75}$ Se-selenate (about 8 nano Curies/sample). After about 2 hours to allow for particle settling, the bottles were reopened, subsampled $(0.5-1.0 \mathrm{~mL})$, and resealed under $\mathrm{N}_{2}$. Subsamples were centrifuged and radioactivity was measured in the supernatant solution (Oremland and others, 1989). All samples were incubated statically at $20^{\circ} \mathrm{C}$, and subsampled after 1, 3, and 8 days as indicated above. In addition, selected samples were incubated with $20 \mathrm{~m} M$ sodium acetate, a substrate for selenate-reducing bacteria, which increases their activity when added to sediments (Oremland and others, 1989).

Results show that after 3 days of incubation there was no loss of selenate from solution in the core materials from 22.8 to $27.8 \mathrm{ft}$, and at $30.8 \mathrm{ft}$ (table 5, fig. 12). In contrast, 78 percent of the labeled selenate in solution was lost in the core from $28.8 \mathrm{ft}$ and 20 percent from the core at $29.8 \mathrm{ft}$. After 8 days, loss of selenate from solution was significant in all nine samples analyzed; however, the samples from $27.8 \mathrm{ft}$ and deeper showed a higher bacterial activity than the shallower samples. In addition, acetate accelerated the selenate loss from the samples at 28.8 and $30.8 \mathrm{ft}$. These results indicate that all the depths assayed have the bacteria present which will reduce selenate; however, the samples from $27.8 \mathrm{ft}$ and deeper have a microbial population capable of reducing selenate at a significant rate while sediments at shallower depths do not. This depth interval corresponds to the zone at which the porewaters become reducing (fig. 10), which is in agreement with the observation that microbial reduction of selenate is an anaerobic process (Oremland and others, 1989).

Analyses of the selenium solid phase that was precipitated in earlier experiments on selenate reduction showed that the selenate was reduced to either the amorphous red elemental selenium or, less frequently, black crystalline elemental selenium (Oremland and others, 1989). The same researchers also reported that very little of the labeled selenium remained in the sample as selenite because this species is a transient intermediate in the reduction of selenate to elemental selenium. 
Table 5. Selenate reduction potential in sediment samples from undisturbed core P1-37 collected August 1988: expressed as percentage of total ${ }^{75} \mathrm{SeO}_{4}$ removed from solution

[ft, feet; --, no data]

\begin{tabular}{llcc}
\hline \multirow{2}{*}{$\begin{array}{c}\text { Depth } \\
(\mathrm{ft})\end{array}$} & Amendment & \multicolumn{2}{c}{$\begin{array}{c}\text { Selenate reduction: } \\
\text { percent of pool reduced in }\end{array}$} \\
\cline { 3 - 4 } & & 3 days & 8 days \\
\hline 22.8 & None & 0 & 20 \\
23.8 & None & 0 & 21 \\
24.8 & None & 0 & 83 \\
25.8 & None & 0 & - \\
25.8 & Acetate & 0 & 12 \\
26.8 & None & 0 & 18 \\
27.8 & None & 0 & 89 \\
28.8 & None & 78 & 90 \\
28.8 & Acetate & 87 & 195 \\
29.8 & None & 20 & 92 \\
30.8 & None & 0 & 92 \\
30.8 & Acetate & 92 & 92 \\
\hline
\end{tabular}

${ }^{1}$ About 25 percent of the selenate in this sample was reduced in the first 24 hours.

The observation that the selenate is removed from solution requires that selenium accumulate in the solid phase. Quantitative recovery of elemental selenium in the solid phase was demonstrated with estuarine sediments (Oremland and others, 1989). In addition, this activity was detected in agricultural waste-pond sediments (Oremland and others, 1990) as well as in a broad survey of sediment types ranging from freshwater to hypersaline (Steinberg and Oremland, 1990). Loss of selenium by degassing of methylated selenides (Frankenburger and others, 1986, 1987) is unlikely to be important below the water table at the site due to the low redox potential and competing anaerobic demethylation reactions (Oremland and Zehr, 1986). Several sediment samples were analyzed in order to determine if there is a zone of higher selenium concentration in the sediments below the peak selenium concentration in the ground water.

Figure 13 shows the range in selenium concentration in two sets of data on San Joaquin Valley soils: data on the selenium concentration in 297 soil samples (0- to 12-inch depth) collected valleywide, and 721 soil samples (66- to 72-inch depth) from the Panoche and Cantua alluvial fans (Tidball and others, 1986). A map of the total selenium concentration of soils in the San Joaquin Valley shows that soil developed from Sierra Nevada sediments almost always contained less than $0.13 \mu \mathrm{g} / \mathrm{g}$ selenium (Tidball and others, 1986), while 90 percent of the soil in the Panoche-Cantua alluvial fans contain greater than $0.32 \mu \mathrm{g} / \mathrm{g}$ selenium (fig. 13). These data suggest that if Sierra Nevada sediments at the site contain selenium concentrations greater than 0.13 $\mu \mathrm{g} / \mathrm{g}$, then these concentrations may be due to addition of selenium to the sediments by reductive removal from infiltrating ground water.

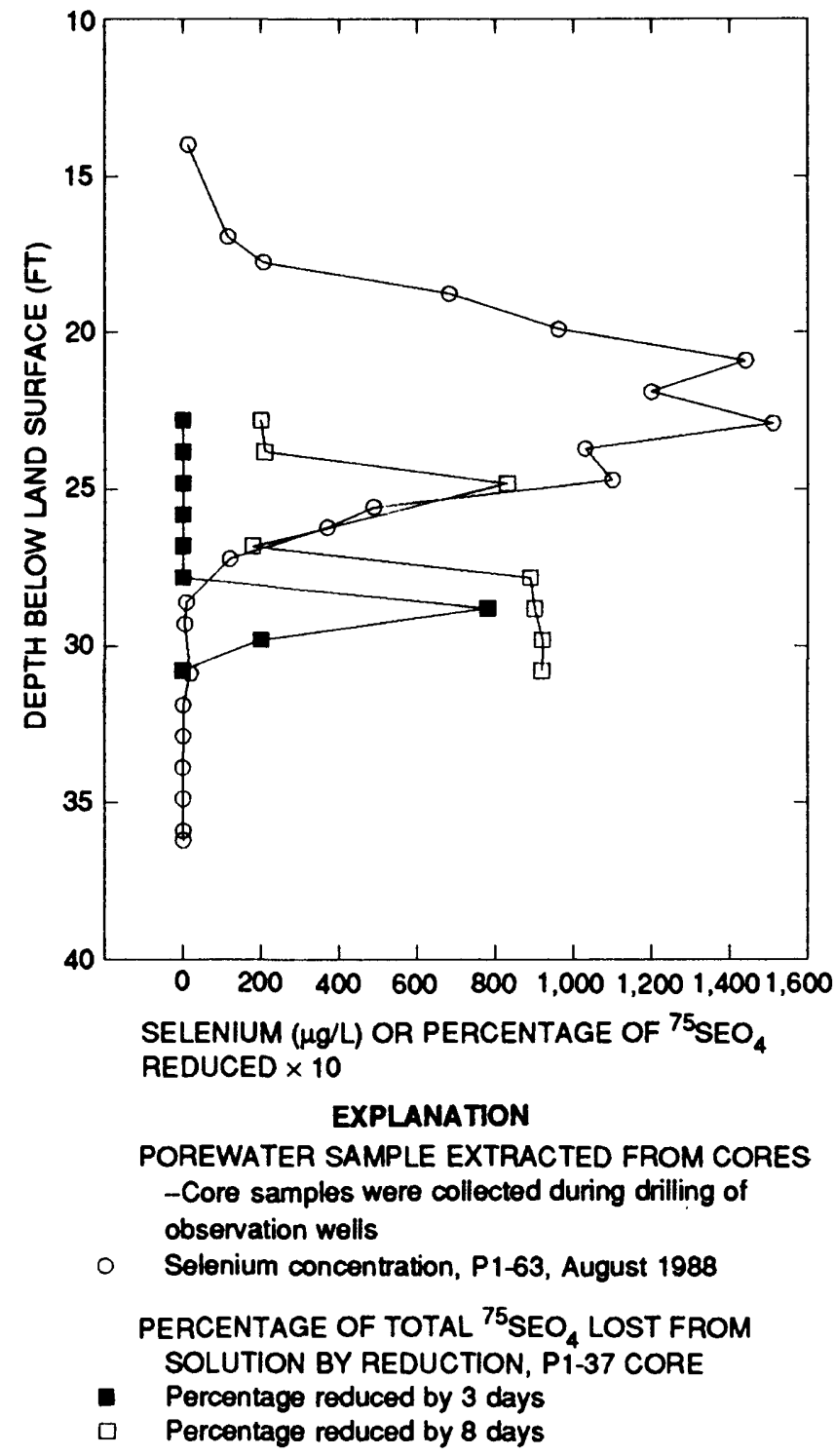

Figure 12. Selenium concentrations in porewater samples from the P1-63 core and results of assays of potential selenate reduction for sediments from the P 1-37 core, expressed as percentage of total ${ }^{75} \mathrm{SeO}_{4}$ lost from solution. (See table 5 .) 


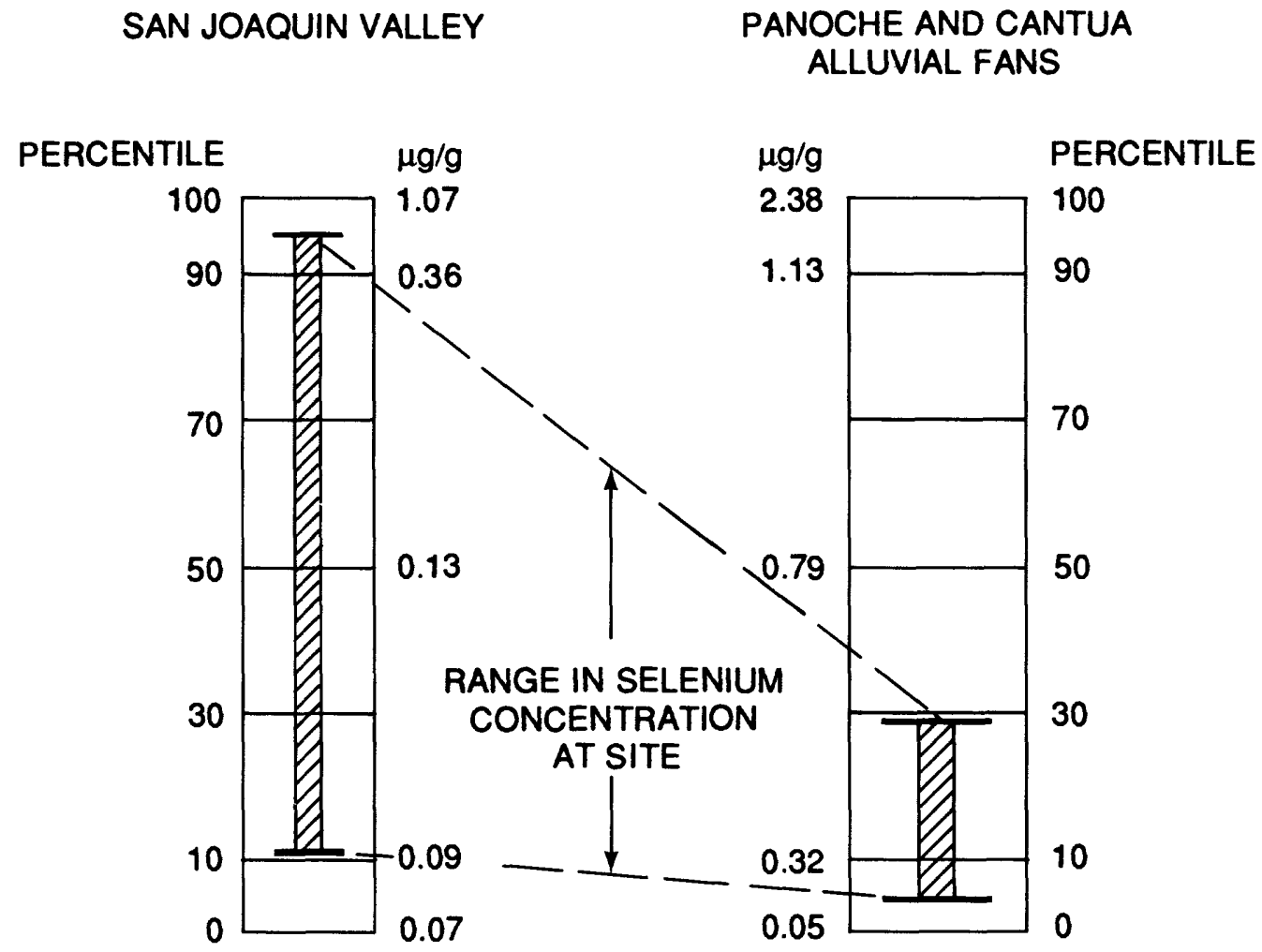

Figure 13. Selenium concentrations in two sets of soil samples in the San Joaquin Valley: 297 soil samples from 0 to 12 inches collected valleywide (left) and 721 soil samples from 66 to 72 inches from the Panoche and Cantua alluvial fans (modified from Gilliom, 1989).

Total selenium concentrations in the sediments ranged from the detection limit of $0.1 \mu \mathrm{g} / \mathrm{g}$ to a maximum of $0.6 \mu \mathrm{g} / \mathrm{g}$ at the same depth as the peak selenium concentration in solution (table 6, fig. 14). Given that the precision of the analysis is $\pm 0.1 \mu \mathrm{g} / \mathrm{g}$, for sediments at depths greater than $25 \mathrm{ft}$, only the samples from 26.6 and $43.9 \mathrm{ft}$ have a selenium concentration greater than expected for Sierra Nevada sediments. There is, therefore, no evidence of a zone of accumulation of solid-phase selenium due to removal from the saline ground water at greater depths. A zone of selenium accumulation would be difficult to identify if either the zone was very narrow, and therefore easily missed, or if the selenium was dispersed in a broad zone in the sediments. A more detailed investigation of the vertical variation of major and trace element concentrations in sediments from the site is in progress.
Table 6. Selenium concentrations in sediment samples from cores P1-55 (1) and P1-49 (2). April 1987

[ft, feet; $\mu \mathrm{g} / \mathrm{g}$, microgram per gram; $\mu \mathrm{g} / \mathrm{L}$, microgram per liter]

\begin{tabular}{cccc}
\hline $\begin{array}{c}\text { Depth } \\
(\mathrm{ft})\end{array}$ & Core & $\begin{array}{c}\text { Selenium, } \\
\text { total in solid } \\
(\mu \mathrm{g} / \mathrm{g})\end{array}$ & $\begin{array}{c}\text { Selenium } \\
\text { in porewater } \\
(\mu \mathrm{g} / \mathrm{L})\end{array}$ \\
\hline 21.6 & 2 & 0.4 & 1,410 \\
22.5 & 1 & .6 & 1,520 \\
24.1 & 2 & .4 & 412 \\
25.3 & 1 & .2 & 33 \\
26.6 & 2 & .3 & 104 \\
29.5 & 1 & .1 & 93 \\
31.6 & 2 & .2 & 9 \\
36.5 & 2 & .1 & 13 \\
43.9 & 2 & .4 & 5 \\
50.9 & 2 & .2 & 2 \\
\hline
\end{tabular}




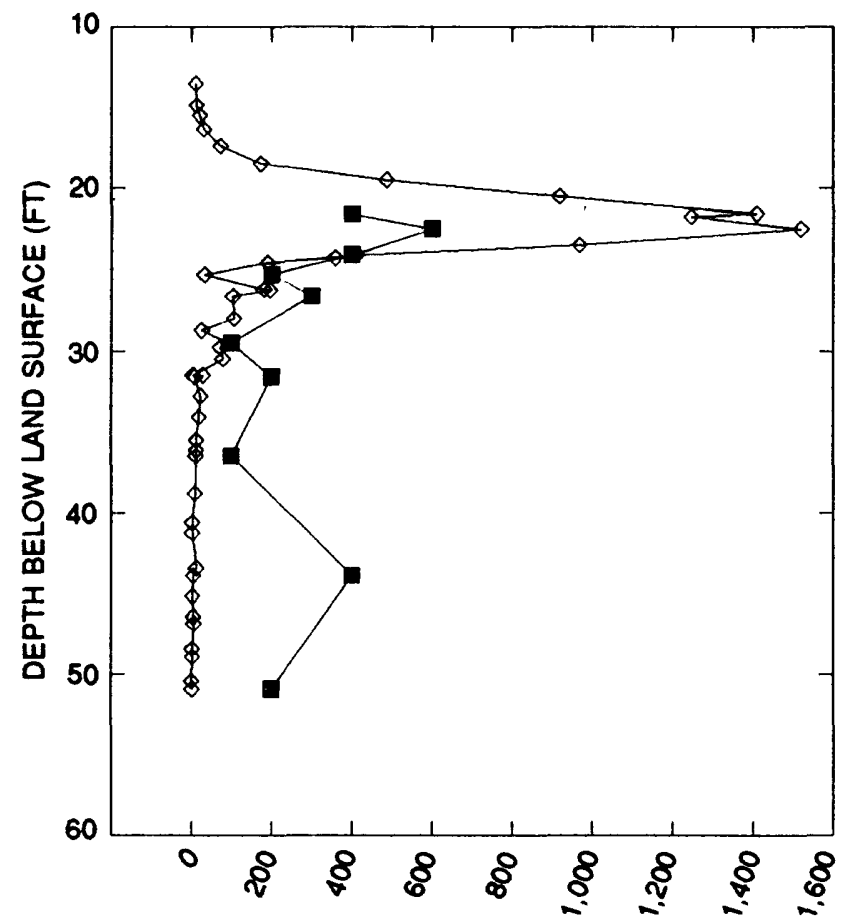

SELENIUM $(\mu \mathrm{g} / \mathrm{L})$ OR SELENIUM $(\mu \mathrm{g} / \mathrm{g}) \times 1,000$

EXPLANATION

$\diamond$ POREWATER-Selenium concentrations $(\mu g / L)$

- SEDIMENT--Selenium concentrations $(\mu g / g)$

Figure 14. Selenium concentrations of porewater and sediment samples extracted from cores during drilling of observation wells $\mathrm{PI}-49$ and Pl-55.

\section{SUMMARY AND CONCLUSIONS}

The influence of redox conditions on selenium transport in shallow ground water was investigated at a site in Mendota, in western San Joaquin Valley, California, where about $50 \mathrm{ft}$ of complexly interbedded sediments from Sierra Nevada and Coast Range sources overlie a thick aquifer of Sierra Nevada origin. The medium- and coarse-grained sand at depths greater than $26 \mathrm{ft}$ below land surface is derived primarily from the Sierra Nevada; however, the fine-grained sediments that dominate the shallower stratigraphy are derived primarily from the Coast Range. Under natural conditions, the site was a discharge area; however, heavy pumping from the underlying aquifer has lowered the water table. Fluctuations in the water-table altitude were caused by deep pumping, and the depth of the water table ranged from $17.6 \mathrm{ft}$ in February 1987 to a maximum of $27.6 \mathrm{ft}$ in August 1988.

Detailed profiles of ground-water geochemistry obtained from wells and porewater extracted from undisturbed cores show saline water at shallow depths. Specific conductance peaks at greater than $20,000 \mu \mathrm{S} / \mathrm{cm}$ at a depth of 36 to $48 \mathrm{ft}$, and decreases to $3,270 \mu \mathrm{S} / \mathrm{cm}$ at a depth of $60 \mathrm{ft}$. All shallow ground water at the site was a sodium chloride type with similar ratios of major cations and anions. Stable-isotope data showed that most of the well water and porewater was similar to local deep ground water and imported irrigation water; however, ground water from $23.5 \mathrm{ft}$ and shallower had been subject to evaporative concentration. Tritium data indicated all of the shallow ground water recharged after 1952, and the age of the ground water decreased with decreasing depth from $60 \mathrm{ft}$ to the water table.

The selenium analyses of ground water samples from observation wells showed a concentration of $480 \mu \mathrm{g} / \mathrm{L}$ at $24.5 \mathrm{ft}$ and concentrations of less than $1 \mu \mathrm{g} / \mathrm{L}$ at all wells $32.5 \mathrm{ft}$ and deeper. Analyses of selenium concentrations in porewater samples from undisturbed cores showed a sharply bounded zone with most selenium concentrations greater than $100 \mu \mathrm{g} / \mathrm{L}$ between 18 and $28 \mathrm{ft}$, and a peak of $1,520 \mu \mathrm{g} / \mathrm{L}$ at $22.5 \mathrm{ft}$. Essentially, all of the selenium occurs as selenate, and the maximum concentration of selenite was $19 \mu \mathrm{g} / \mathrm{L}$ (4 percent of the total concentration). Selenium and specific conductance were not correlated in ground water at the site, in contrast to the high correlation observed for ground water from oxidized Coast Range sediments to the west.

Redox potential of ground water greatly affects the distribution of selenium in San Joaquin Valley ground water due to the low mobility of the reduced selenium species. Redox potential of ground water at the site was evaluated on the basis of platinum electrode potential and the abundance of redox-sensitive dissolved constituents. These redox indicators suggest that the lack of correlation of selenium and salinity is due to removal of selenium from solution by reduction to a less soluble species. This is inferred by the 
coincidence of the lower boundary of the high selenium zone with (1) decreasing platinum electrode redox potentials, (2) the disappearance of dissolved oxygen and nitrate, and (3) a rapid increase in iron and manganese concentrations.

Laboratory analyses of undisturbed cores indicate that the potential for microbial selenate reduction is significant at depths greater than $27 \mathrm{ft}$ below land surface. These results, along with results of other researchers working in similar geochemical systems, indicate that the mechanism of selenium removal likely is microbial reduction to insoluble elemental selenium. Analysis of sediment samples showed no zone of accumulation of selenium as would be expected if high concentrations of selenium had been transferred from the solution to the solid phase; however, such a zone would have gone undetected if it were a narrow zone that was missed or a broad zone resulting in little increase above background.

The conceptual model for the site consists of the evolution of saline soil with high selenium concentrations in a regional ground-water discharge area prior to agricultural development; downward migration of saline, seleniferous ground water due to water-table drawdown; and selenium removal from the downward-migrating ground water by microbially mediated redox reactions.

\section{REFERENCES CITED}

Balistrieri, L.S., and Chao, T.T., 1987, Selcnium adsorption by goethite: Soil Science Society of America, v. 51, p. 1145-1151.

Belitz, Kenneth, and Heimes, F.J., 1990, Character and evolution of the ground-water flow system in the central part of the western San Joaquin Valley, California: U.S. Geological Survey Water-Supply Paper 2348, $28 \mathrm{p}$.

Benson, S.M., Solbau, R., and Daggett, J., 1988, Tracer experiments for evaluating reactive and nonreactive (nitrate and selenium) transport under Kesterson Reservoir: Eos Transactions, American Geophysical Union, v. 69, no. 44, p. 1191.

Bricker, O.P., 1982, Redox potential: its measurement and importance in water systems, chap. 2 in Water Analysis: New York, Academic Press, v. 1, p. 55-83.

Bull, W.B., and Miller, R.E., 1975, Land subsidence due to ground-water withdrawal in the Los Banos-Kettleman City area, California, Part 1. Changes in the hydrologic environment conducive to subsidence: U.S. Geological Survey Professional Paper 437-E, $71 \mathrm{p}$.

California Division of Mines and Geology, 1959, Geologic maps of California, Santa Cruz sheet: California Department of Conservation, scale 1:250,000, 2 sheets.
Davis, G.H., and Coplen, T.B., 1989, Late Cenozoic paleometeorology and structural history of the central Coast Ranges deduced by chemical and isotopic hydrology of ground water of the central west side of the San Joaquin Valley, California: Geologic Society of America Special Publication.

Davis, G.H., Green, J.H.. Olmsted, F.H., and Brown, D.W., 1959 , Ground-water conditions and storage capacity in the San Joaquin Valley, California: U.S. Geological Survey Water-Supply Paper 1469, 287 p.

Davis, G.H., and Poland, J.F., 1957, Ground-water conditions in the Mendota-Huron area, Fresno and Kings Counties, California: U.S. Geological Survey Water-Supply Paper 1360-G, p. 409-588.

Desaulniers, D.E., Cherry, J.A., and Fritz, Peter, 1981, Origin, age, and movement of porewater in argillaceous Quaternary deposits at four sites in southwestern Ontario: Journal of Hydrology, v. 50, p. 231-257.

Deverel, S.J., and Fujii, Roger, 1988, Processes affecting the distribution of selenium in shallow ground water of agricultural areas, western San Joaquin Valley, California: Water Resources Research, v. 24, no. 4, p. 516-524.

Deverel, S.J., and Gallanthine, S.K., 1989, Relation of salinity and selenium in shallow ground water to hydrologic and geochemical processes, western San Joaquin Valley, California: Journal of Hydrology, v. 109 , p. $125-149$.

Deverel, S.J., Gilliom, R.J., Fujii, Roger, Izbicki, J.A., and Fields, J.C., 1984, Areal distribution of selenium and other inorganic constituents in shallow ground water of the San Luis Drain service area, San Joaquin Valley, California: A preliminary study: U.S. Geological Survey Water-Resources Investigations Report 84-4319, $67 \mathrm{p}$.

Deverel, S.J., and Millard, S.P., 1988, Distribution and mobility of selenium and other trace elements in shallow groundwater of the western San Joaquin Valley, California: Environmental Science and Technology, v. 22 , no. 6, p. 697-702.

Dubrovsky, N.M., 1989, Selenium in ground water of the northern part of the western valley, in Gilliom, R.G., and others, Preliminary assessment of sources, distribution, and mobility of selenium in the San Joaquin Valley, California: U.S. Geological Survey WaterResources Investigations Report 88-4186, p. 67-75.

Dubrovsky, N.M., and Deverel, S.J., 1989, Selenium in ground water of the central part of the western valley, in Gilliom, R.G., and others, Preliminary assessment of sources, distribution, and mobility of selenium in the San Joaquin Valley, California: U.S. Geological Survey Water-Resources Investigations Report 88-4186, p. 35-66.

Elrashadi, A.M., Adriano, D.C., Workman, S.M., and Lindsay, W.L., 1987, Chemical equilibria of selenium in soils: A theoretical development: Soil Science, v. 144 , no. 2 , p. 141-152.

Epstein, S. and Mayeda, T., 1953, Variations in the 0-18 content of waters from natural sources: Geochimica et Cosmochimica Acta., v. 4, p. 213-224. 
Fio, J.L., and Fujii, Roger, 1990, Selenium speciation methods and application to soil saturation extracts from San Joaquin Valley, California: Soil Science Society of America, v. 54, no. 2, p. 363-369.

Frankenburger, W.T., Jr., Bradford, G.R., Karlson, U., 1987, Removal of selenium from agricultural drainage water through soil microbial transformations, in Tanji, K.K., and others (eds.), 1986-87 Technical Progress Report, UC Salinity/Drainage Task Force: Davis, University of California, Division of Agriculture and Natural Resources, p. 62-66.

Frankenburger, W.T., Jr., Farmer, F., Focht, D., Jury, W., and Spencer, W., 1986, Microbial transformations in seleniferous soils, in Tanji, K.K., and others (eds.), 1985-86 Technical Progress Report, UC Salinity/ Drainage Task Force: Davis, University of California, Division of Agriculture and Natural Resources, p. 75-80.

Gardner, W.R., and Fireman, M., 1958, Laboratory studies of evaporation from soil columns in the presence of a water table: Soil Science of America, Proceedings, v. 85 , p. $244-249$.

Gilliom, R.J., 1989, Geologic source of selenium and its distribution in soil, in Gilliom, R.G., and others, Preliminary assessment of sources, distribution, and mobility of selenium in the San Joaquin Valley, California: U.S. Geological Survey Water-Resources Investigations Report 88-4186, p. 7-11.

Goldberg, S., and Glaubig, R.A., 1988, Anion sorption on a calcareous, montmorillonitic soil-selenium: Soil Science Society of America, v. 52, no. 4, p. 954-958.

Grisak, G.E., and Pickens, J.F., 1980, Solute transport through fractured media, 1, The effect of matrix diffusion: Water Resources Research, v. 16, no. 4, p. 719-730.

Hamilton, F., 1916, Geological map of the State of California: California Division of Mines and Geology, 1 sheet.

Harradine, F.F., 1950, Soils of western Fresno County: Berkeley, University of California Press, 86 p.

Harshman, E.N., 1972, Geology and uranium deposits, Shirley Basin area, Wyoming: U.S. Geological Survey Professional Paper 745, $82 \mathrm{p}$.

Hotchkiss, W.R., and Balding, G.O., 1971, Geology, hydrology, and water quality of the Tracy-Dos Palos area, San Joaquin Valley, California: U.S. Geological Survey Open-File report, 107 p.

International Atomic Energy Agency, 1976, Procedures and techniques critique of tritium enrichment by electrolysis: International Atomic Energy Agency Technical Note 19, Vienna.

----1981, Statistical treatment of environmental isotope data in precipitation: International Atomic Energy Agency Technical Report, Series no. 2, 2 p.

Kendall, C., and Coplen, T.B., 1985, Multisample conversion of water to hydrogen by zinc for stable isotope determination: Analytical Chemistry, v. 57, p. 1437-1440.
Langmuir, D., 1971, Eh-pH determination: in Procedures in Sedimentary Petrology, Robert E. Carver, (ed.): New York, John Wiley, p. 597-634.

Lawrence Berkeley Laboratory, 1987, Hydrological, geochemical, and ecological characterization of Kesterson Reservoir: Annual Report, October 1, 1986, through September 30, 1987: Berkeley, University of California, Earth Sciences Division, Lawrence Berkeley Laboratory, $174 \mathrm{p}$.

-.---1988, Hydrological, geochemical, and ecological characterization of Kesterson Reservoir: Annual Report, October 1, 1987, through September 30, 1988: Berkeley, University of California, Earth Sciences Division, Lawrence Berkeley Laboratory, 229 p.

Lettis, W.R., 1982, Late Cenozoic stratigraphy and structure of the western margin of the central San Joaquin Valley, California: U.S. Geological Survey Open-File Report 82-526, 203 p.

Lindberg, R.D., and Runnells, D.D., 1984, Groundwater redox reactions: An analysis of equilibrium state applied to Eh measurements and geochemical modeling: Science, v. 225, p. 925-927.

Macy, J.M., Michel, T.A., and Kirsch, D.G., 1989, Selenate reduction by a Pseudomonas species: a new mode of anaerobic respiration: Federation of European Microbiological Societies, Microbiological Letters 61, p. 195-198.

Manheim, F.T., 1966, A hydraulic squeezer for obtaining interstitial water from consolidated and unconsolidated sediments: U.S. Geological Survey Professional Paper 550-C, p. C256-C261.

Masscheleyn, P.H., Delavne, R.D., and Patrick, W.H., Jr., 1989, Transformations of selenium as affected by sediment oxidation-reduction potential and $\mathrm{pH}$ : Environmental Science and Technology, v. 24, no. 1, p. 91-96.

Meade, R.H., 1967, Petrology of sediments underlying areas of land subsidence in central California: U.S. Geological Survey Professional Paper 497-C, 83 p.

Mendenhall, W.C., Dole, R.B., and Stabler, Herman, 1916, Ground water in the San Joaquin Valley, California: U.S. Geological Survey Water-Supply Paper 398, $310 \mathrm{p}$.

Miller, R.E., Green, J.H., and Davis, G.H., 1971, Geology of the compacting deposits in the Los Banos-Kettleman City subsidence area, California: U.S. Geological Survey Professional Paper 497-E, 46 p.

Neal, R.H., Sposito, G., Holtzclaw, K.M., and Traina, S.J., 1987a, Selenite adsorption on alluvial soils: I. Soil composition and $\mathrm{pH}$ effect: Soil Science Society of America, v. 51, p. 1161-1165.

1987b, Selenite adsorption on alluvial soils: II. Solution composition effects: Soil Science Society of America, v. 51, p. 1165-1169.

Nordstrom, D.K., 1977, Thermochemical redox equilibria of ZoBell's solution: Geochimica et Cosmochimica Acta., v. 41 , p. 1835-1842. 
Ohlendorf, H.M., Hothem, R.L., Bunck, C.M., Aldrich, T.W., and Moore, J.F., 1986, Relationships between selenium concentrations and avian reproduction: North American Wildlife and Natural Resources Conference, 51st, Reno, Nevada, Transactions, 1986, p. 330-442.

Oremland, R.S., Hollibaugh, J.T., Maest, A.S., Presser, T.S., Miller, L.G., and Culbertson, C.W., 1989, Selenate reduction to elemental selenium by anaerobic bacteria in sediments and culture: biogeochemical significance of a novel, sulfate-independent respiration: Applied and Environmental Microbiology, v. 55, p. 2333-2343.

Oremland, R.S., and Polcin, S.P., 1982, Methanogenesis and sulfate reduction: competitive and non-competitive substrates in estuarine sediments: Applied and Environmental Microbiology, v. 44, p. 1270-1276.

Oremland, R.S., Steinberg, N.S., Maest, A.S., Miller, L.G., and Hollibaugh, J.T., 1990, Measurement of in situ rates of selenate removal by dissimilatory bacterial reduction in sediments: Environmental Science and Technology (in press).

Oremland, R.S., and Zehr, J.P., 1986, Formation of carbon dioxide and methane from dimethylselenide in anoxic sediments and by a methanogenic bacterium: Applied and Environmental Microbiology, v. 52, p. 1031-1036.

Presser, T.S., Swain, W.C., Tidball, R.R., and Severson, R.C., 1990, Geologic sources, mobilization, and transport of selenium from the California Coast Ranges to the western San Joaquin Valley: a reconnaissance study: U.S. Geological Survey Water-Resources Investigations Report 90-4070, 66 p.

San Joaquin Valley Drainage Program, 1989, Preliminary planning alternatives for solving agricultural drainage and drainage-related problems in the San Joaquin Valley: San Joaquin Valley Drainage Program, August 1989, (various pagination).

Siever, R., 1962, A squeezer for extracting interstitial water: Journal of Sedimentary Petrology, v. 32, p. 329-331.
Skougstad, M.W., Fishman, M.J., Friedman, L.C., Erdmann, D.E., and Duncan, S.S., (eds.), 1985, Methods for determination of inorganic substances in water and fluvial sediments: U.S. Geological Survey Techniques of Water-Resources Investigations, Book 5, Chapter A1, 709 p.

Steinberg, N., and Oremland, R.S., 1990, Microbial reduction of $\mathrm{SeO}_{4}=$ to $\mathrm{Se}^{0}$ in sediments of widely diverse environments: American Society of Microbiology Annual Meeting, $1 \mathrm{p}$.

Stumm, Werner, and Morgan, J.J., 1981, Aquatic chemistry (2d ed.): New York, Wiley Interscience, $780 \mathrm{p}$.

Sudicky, E.A., and Frind, E.O., 1981, Carbon-14 dating of groundwater in confined aquifers: implications of aquitard diffusion: Water Resources Research, v. 17, no. 4, p. 1060-1064.

Thorstenson, D.C., 1984, The concept of electron activity and its relation to redox potentials in aqueous geochemical systems: U.S. Geological Survey Open-File Report 84-072, 45 p.

Tidball, R.R., Grundy, W.D., and Sawatzky, D.L., 1986, Kriging techniques applied to element distribution in soils of the San Joaquin Valley, California: HAZTECH International Conference, Denver, Colorado, August 11-15, 1986, Proceedings, p. 992-1009.

Weres, O., Jaouni, A.-R., and Tsao, L., 1989, The distribution, speciation, and geochemical cycling of selenium in a sedimentary environment, Kesterson Reservoir, California, U.S.A.: Applied Geochemistry, v. 4, p. 543-563.

White A.F., 1988, Geochemical controls on selenium mobility in ground water at the Kesterson Reservoir: Eos Transactions, American Geophysical Union, v. 69, no. 44, p. 1191.

Whitfield, M., 1974, Thermodynamic limitations on the use of the platinum electrode in Eh measurements: Limnology Oceanography, v. 19, p. 857-865. 